\title{
The contribution of wood burning and other pollution sources to wintertime organic aerosol levels in two Greek cities
}

\author{
Kalliopi Florou $^{1,2}$, Dimitrios K. Papanastasiou ${ }^{1,2}$, Michael Pikridas ${ }^{3}$, Christos Kaltsonoudis ${ }^{1,2}$, Evangelos Louvaris ${ }^{1,2}$, \\ Georgios I. Gkatzelis $^{1,2}$, David Patoulias ${ }^{1,2}$, Nikolaos Mihalopoulos ${ }^{4,5}$, and Spyros N. Pandis ${ }^{1,2,6}$ \\ ${ }^{1}$ Institute of Chemical Engineering Sciences, ICE/FORTH, Patras, Greece \\ ${ }^{2}$ Department of Chemical Engineering, University of Patras, Patras, Greece \\ ${ }^{3}$ The Cyprus Institute, Environment Energy and Water Research Center, Nicosia, Cyprus \\ ${ }^{4}$ Department of Chemistry, University of Crete, Heraklion, Greece \\ ${ }^{5}$ IERSD, National Observatory of Athens, Athens, Greece \\ ${ }^{6}$ Department of Chemical Engineering, Carnegie Mellon University, Pittsburgh, USA
}

Correspondence to: Spyros N. Pandis (spyros@chemeng.upatras.gr)

Received: 10 August 2016 - Discussion started: 22 August 2016

Revised: 23 January 2017 - Accepted: 24 January 2017 - Published: 1 March 2017

\begin{abstract}
The composition of fine particulate matter (PM) in two major Greek cities (Athens and Patras) was measured during two wintertime campaigns, one conducted in 2013 and the other in 2012. A major goal of this study is to quantify the sources of organic aerosol (OA) and especially residential wood burning, which has dramatically increased due to the Greek financial crisis. A high-resolution time-of-flight aerosol mass spectrometer (HR-ToF-AMS) was deployed at both sites. $\mathrm{PM}$ with diameter less than $1 \mu \mathrm{m}\left(\mathrm{PM}_{1}\right)$ consisted mainly of organics (60-75\%), black carbon (5-20\%), and inorganic salts (around 20\%) in both Patras and Athens. In Patras, during evening hours, $\mathrm{PM}_{1}$ concentrations were as high as $100 \mu \mathrm{g} \mathrm{m}^{-3}$, of which $85 \%$ was OA. In Athens, the maximum hourly value observed during nighttime was $140 \mu \mathrm{g} \mathrm{m}^{-3}$, of which $120 \mu \mathrm{g} \mathrm{m}^{-3}$ was OA. Forty to $60 \%$ of the average OA was due to biomass burning for both cities, while the remaining mass originated from traffic (12-17\%), cooking (12-16\%), and long-range transport (18-24\%). The contribution of residential wood burning was even higher (80-90\%) during the nighttime peak concentration periods, and less than $10 \%$ during daytime. Cooking OA contributed up to $75 \%$ during mealtime hours in Patras, while trafficrelated $\mathrm{OA}$ was responsible for $60-70 \%$ of the OA during the morning rush hour.
\end{abstract}

\section{Introduction}

Fine particulate matter is associated with premature mortality and cardiovascular disease (Nel, 2005), and it also impacts climate, visibility, and ecosystems (Grantz et al., 2003; Hallquist et al., 2009; Watson, 2002). An important fraction of submicrometer PM is organic, representing 20-90\% of $\mathrm{PM}_{1}$ mass worldwide (Jimenez et al., 2009; Zhang et al., 2007) and originating from various anthropogenic and natural sources. Organic aerosol (OA) can either be emitted directly in particulate form and considered primary (POA) or be produced in the atmosphere by oxidation of organic gaseous precursors and considered secondary (SOA; Kanakidou et al., 2005; Turpin and Huntzicker, 1995). POA is emitted during combustion of fossil fuels, biomass burning, cooking, etc. (Hallquist et al., 2009; He et al., 2010; Mohr et al., 2009).

Aerosol mass spectrometry can quantify the mass spectra of OA and helps identify its sources (Jayne et al., 2000). Source apportionment techniques, such as positive matrix factorization (PMF), are widely used in order to estimate the contributions of the various OA sources (Lanz et al., 2007; Mohr et al., 2009; Paatero and Tapper, 1994). Sources that are often identified include oxygenated OA (OOA), hydrocarbon-like OA (HOA), biomass burning OA (BBOA), and cooking OA (COA; Aiken et al., 2009; He et al., 2010; 
Herndon et al., 2008; Huang et al., 2011; Mohr et al., 2009; Saarikoski et al., 2012; Zhang et al., 2007).

During wintertime, wood burning for domestic heating purposes is one of the main sources of OA in several countries (Alfarra et al., 2007; Puxbaum et al., 2007). Biomass burning is a major source of gas- and particle-phase air pollution on urban (Robinson et al., 2006; Schauer and Cass, 2000), regional (Watson, 2002; Wotawa and Trainer, 2000), and global (Bond et al., 2004; Lelieveld et al., 2001) scales. Violations of daily PM standards due to wood burning have been reported in major European cities such as London, Paris, and Berlin (Fuller et al., 2013, 2014). In several countries while traffic and industrial emissions are decreasing, the impact of residential wood burning emissions on air quality is increasing (Favez et al., 2010).

In Greece, the use of woodstoves and fireplaces has increased dramatically during the last few years. Pikridas et al. (2013) reported that biomass burning for heating purposes was the dominant source of OA during wintertime in $\mathrm{Pa}$ tras, the third-biggest city of Greece. Elevated mass concentrations of $\mathrm{PM}_{2.5}$ (diameter less than $2.5 \mu \mathrm{m}$ ) due to wood burning were also observed in the capital and largest city of Greece, Athens, coinciding with the beginning of the economic crisis in Greece (Paraskevopoulou et al., 2014). Measurements conducted during 2010 and 2012 in the city of Thessaloniki (Petrakakis et al., 2013) showed an increase of $\mathrm{PM}_{10}$ (diameter less than $10 \mu \mathrm{m}$ ) by $13 \%$ and $\mathrm{PM}_{2.5}$ by $25 \%$ during domestic heating hours. Gaidajis et al. (2014) reported the same behavior in Northern Greek cities (Kavala and Drama), where the daily average $\mathrm{PM}_{1}$ concentrations exceeded $40 \mu \mathrm{g} \mathrm{m}^{-3}$.

In this study, a high-resolution time-of-flight aerosol mass spectrometer (HR-ToF-AMS) was deployed in order to investigate the chemical composition of $\mathrm{PM}_{1}$ in two Greek cities (Athens and Patras) during two different wintertime periods (2012 and 2013). The PMF source apportionment algorithm, used unconstrained, was applied to the corresponding datasets, estimating the contributions of the different $\mathrm{OA}$ sources, without assuming any a priori knowledge of their origin. Previous studies in these areas have relied on filterbased measurements of the $\mathrm{PM}_{2.5}$ and $\mathrm{PM}_{10}$ concentrations (Argyropoulos et al., 2012; Chaloulakou et al., 2003; Katragkou et al., 2009; Koulouri et al., 2008; Theodosi et al., 2011) and had limited or no information about the composition of the OA. Few PM source apportionment studies are available for Athens. Dall' Osto and Harrison (2006) using an aerosol time-of-flight mass spectrometer (ATOFMS) found two dominant particle types in Athens: calcium-rich dust particles and secondary carbonaceous ones. The main objective of this paper is to quantify the contribution of wood combustion and the fine PM levels of additional OA sources in the corresponding areas during wintertime.

\section{Experimental section}

\subsection{Measurement sites}

\subsubsection{Patras}

Patras is the third-biggest city of Greece, with 300000 inhabitants, and is situated at the foothills of Mount Panachaikon, overlooking the Gulf of Patras, $220 \mathrm{~km}$ west of Athens. The instruments were housed inside the campus of the Technological Educational Institute (TEI) of Patras $\left(38^{\circ} 13^{\prime} \mathrm{N}\right.$, $21^{\circ} 45^{\prime} \mathrm{E}$ ) and monitored from 26 February to 5 March 2012. The TEI is in the southwest of the city, surrounded by moderate-traffic streets and houses, and is considered an urban site (Fig. S1 in the Supplement). Measurements of black carbon (BC) were made at the center of the city $\left(38^{\circ} 14^{\prime} \mathrm{N}\right.$, $21^{\circ} 44^{\prime} \mathrm{E}$ ), approximately $4 \mathrm{~km}$ away from the main site. A more detailed description of the two sites and the instrumentation used can be found in Pikridas et al. (2013).

\subsubsection{Athens}

Athens is the capital and largest city of Greece, with approximately 5 million inhabitants within the greater Athens metropolitan area, which represents almost half of the country's population (Fig. S1). An extensive campaign was conducted in the center of Athens from 10 January until 9 February 2013, the year following the Patras campaign. The measurements took place on the premises of the National $\mathrm{Ob}$ servatory of Athens (NOA) at Thiseio $\left(37^{\circ} 58^{\prime} \mathrm{N}, 23^{\circ} 43^{\prime} \mathrm{E}\right)$. NOA is situated on the small hill of the Nymphs ( $100 \mathrm{~m}$ a.s.l.: meters above sea level), overlooking the Acropolis and near the city center of Athens.

\subsection{Instrumentation}

The same instruments and sampling approach were used during both campaigns. More specifically:

HR-ToF-AMS The Aerodyne AMS, developed by Jayne et al. (2000), can provide continuous quantitative size and composition information for the non-refractory (NR) components of submicron atmospheric aerosol in real time. The chemical composition of NR-PM 1 organic and inorganic (nitrate, sulfate, ammonium and partially potassium) aerosol particles was monitored using a HR-ToF-AMS (Canagaratna et al., 2007; DeCarlo et al., 2006; Drewnick et al., 2005). The sample during this study was not dried, and the vaporizer surface temperature was set at $600^{\circ} \mathrm{C}$. The HR-ToF-AMS measurements during both campaigns alternated between the $\mathrm{V}$ and $\mathrm{W}$-modes every $3 \mathrm{~min}$, but only the $\mathrm{V}$-mode data are presented here.

SMPS The ambient aerosol number distribution, for particles smaller than $500 \mathrm{~nm}$ in diameter, was measured by a TSI scanning mobility particle sizer (SMPS; model 3081) coupled with a condensation particle counter (CPC; model 3775). The system operated at a sheath flow rate of $5 \mathrm{~L} \mathrm{~min}^{-1}$ 
and a sample flow rate of $1 \mathrm{~L} \mathrm{~min}^{-1}$, without drying the sample.

MAAP $\mathrm{PM}_{2.5}$ aerosol absorption was monitored continuously during the two campaigns by a multi-angle absorption photometer (MAAP, Thermo Scientific Inc. model 5012). The MAAP estimates BC mass loadings by combining aerosol optical absorption and back scattering (Petzold and Schönlinner, 2004). The MAAP was set at a wavelength of $670 \mathrm{~nm}$ during the measurements, and its inlet was heated to $70^{\circ} \mathrm{C}$.

PTR-MS The volatile organic compounds (VOCs) during the Athens campaign were measured by a protontransfer-reaction mass spectrometer (PTR-MS, Ionicon Analytik Inc.), the operation principles and application details of which can be found in Steinbacher et al. (2004). Additional information and analysis about these VOC measurements during the sampling period are presented by Kaltsonoudis et al. (2016).

Other instrumentation The aerosol volatility was quantified using a thermodenuder (TD), based on the design of An et al. (2007). A detailed analysis of these measurements is presented in Louvaris et al. (2017) and Gkatzelis et al. (2016). The concentrations of carbon monoxide (CO), carbon dioxide $\left(\mathrm{CO}_{2}\right)$, nitrogen oxides $\left(\mathrm{NO}_{x}\right)$, and ozone $\left(\mathrm{O}_{3}\right)$ were measured by the corresponding Teledyne monitors (models 300E, T360, T201, and 400E, respectively). Additional information is presented by Kaltsonoudis et al. (2016). Also, three different filter samplers were used in order to collect $\mathrm{PM}_{2.5}$ samples for the measurement of organic carbon (OC), elemental carbon (EC), water-soluble organic carbon (WSOC), and the main ions $\left(\mathrm{NH}_{4}^{+}, \mathrm{SO}_{4}^{2-}\right.$, and $\left.\mathrm{NO}_{3}^{-}\right)$. The Met One SuperSASS (Speciation Air Sampler System) was deployed during the Patras campaign, while a dichotomous Partisol sampler (Rupprecht \& Patashnick Co., Inc.) and a Partisol FRM (Federal Reference Method) Model 2000 were used in Athens. Both Teflon and quartz fiber filters were used in Athens and Patras at daily, $12 \mathrm{~h}$ and $6 \mathrm{~h}$ collection intervals. Details about the filter extraction procedure and chemical analysis can be found in Pikridas et al. (2013) and Paraskevopoulou et al. (2014).

\subsection{AMS data analysis}

All HR-ToF-AMS data were analyzed using the standard AMS software toolkit (SQUIRREL v1.53), while the highresolution data were processed using the Peak Integration by Key Analysis (PIKA v1.10C; Sueper, 2011) software, within Igor Pro 6.34A (Wave Metrics). For the determination of the elemental ratios measured by the HR-AMS both the method of Aiken et al. (2008) and the improved ambient calculation approach proposed by Canagaratna et al. (2015) were used. In order to calculate the collection efficiency (CE) of the HR-ToF-AMS, we combined the HR-ToF-AMS mass distributions and the SMPS volume distributions (for particle diameters between 10 and $500 \mathrm{~nm}$ ), applying the algorithm of

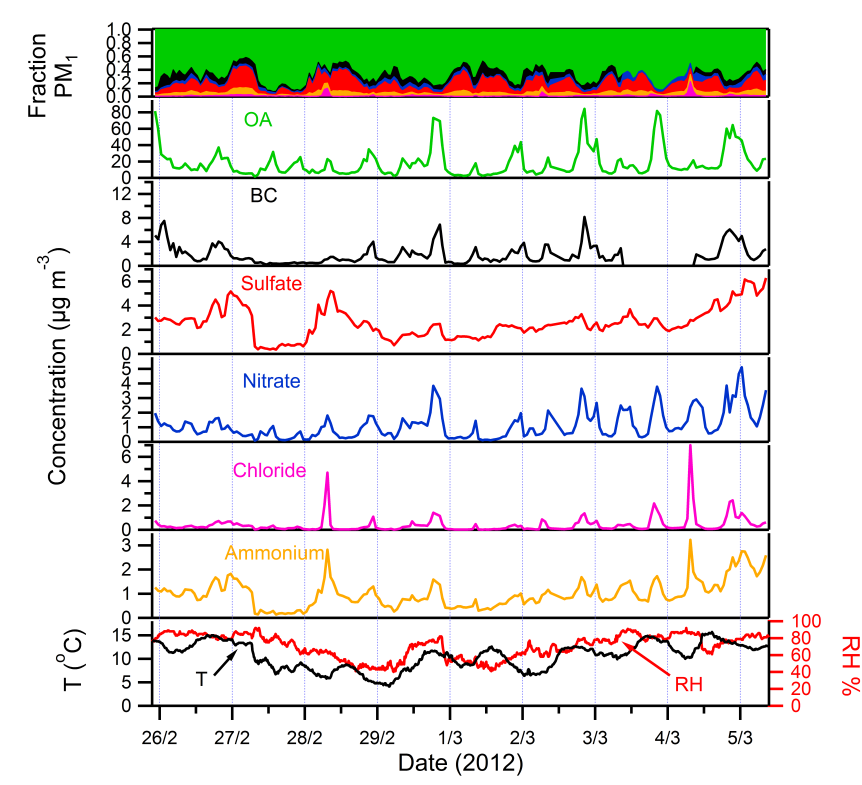

Figure 1. Fractional contribution and time series (hourly averages) of the main $\mathrm{PM}_{1}$ species during the Patras campaign. Also shown are the temperature and $\mathrm{RH}$.

Kostenidou et al. (2007) every $2 \mathrm{~h}$. The algorithm was modified to take into account the $\mathrm{BC}$ measured by the MAAP, assuming that the $\mathrm{BC}$ had the same size distribution as the OA.

PMF analysis (Lanz et al., 2007; Paatero and Tapper, 1994; Ulbrich et al., 2009) was performed using as input the HRAMS organic mass spectra $(m / z$ values $12-200)$ in order to determine the different OA sources. The mass spectra of the identified factors and those in the literature have been compared using the theta angle $(\theta)$ between the corresponding vectors (Kostenidou et al., 2009). This method treats mass spectra signals as vectors in a multi-dimensional space, with size equal to the number of $m / z$ values used. Two spectra are considered to be the same if the angle $\theta$ between them is zero. In practice, a low value of the theta angle (less than $10^{\circ}$ ) indicates high similarity between the two spectra. This approach has been utilized by commercially available software to match unknown mass spectra with references from mass spectral libraries (Stein and Scott, 1994). For the comparison of the OOA and HOA spectra with the ones in the literature, only HR spectra using the fragmentation table by Aiken et al. (2009) were used. The BBOA and COA spectra have been compared with almost all the corresponding spectra found in the database (both HR and unit mass resolution), resulting in higher theta values due to differences at $m / z 18$, 28 , and 39. By excluding these specific $m / z$ values, the theta angle decreased. 


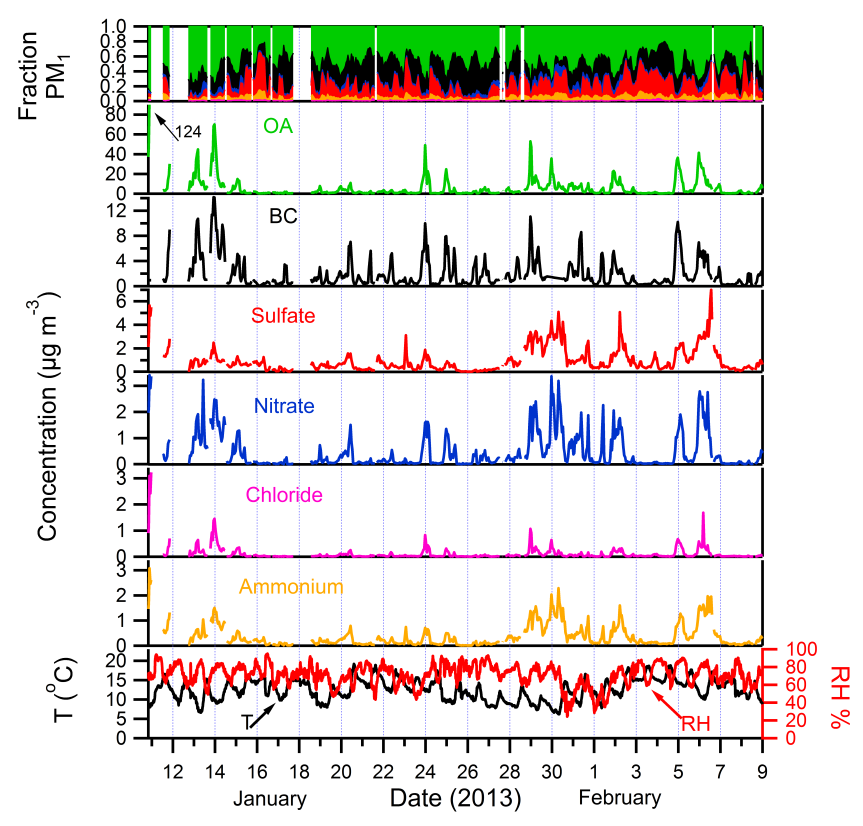

Figure 2. Fractional contribution and time series (hourly averages) of the main $\mathrm{PM}_{1}$ species during the Athens campaign. Also shown are the temperature and RH. During the first day, OA reached levels up to $124 \mu \mathrm{g} \mathrm{m}^{-3}$.

\section{Meteorology}

During the Patras campaign, the ambient temperature ranged from 4 to $16^{\circ} \mathrm{C}$, with an average of $11^{\circ} \mathrm{C}$. The average relative humidity (RH) was $75 \%$ (ranging from 40 to $90 \%$; Fig. 1). Three types of air masses were identified using back-trajectory analysis based on FLEXPART (FLEXible PARTicle dispersion model; Stohl et al., 2005) during the campaign (Fig. S2). The periods 25-26 February and 3-4 March were characterized by air masses coming predominantly from western Greece (44\% of the air masses). During 26-27 February and 5 March the air masses had marine origin $(14 \%)$, while air masses during 28 February to 2 March originated from central Greece and the Balkans (42\%). Examples of the three categories are depicted in Fig. S3.

During the Athens campaign, the average ambient temperature was $12.5^{\circ} \mathrm{C}$ (ranging from 6 to $19^{\circ} \mathrm{C}$ ), while the average RH was $71 \%$ (ranging from 25 to $95 \%$; Fig. 2). FLEXPART indicated four types of air masses arriving at the site. The first type originated from Africa and passed over the Mediterranean Sea. The second had marine origin coming from the west often passing over Sicily. The third came from the NE, passing over the Aegean and the eastern Balkans. Finally, the fourth type included air masses from central Greece and the western Balkans. Examples of these trajectories are depicted in Fig. S4, and a summary of the air masses observed is provided in Fig. S5.

\section{$4 \mathrm{PM}_{1}$ chemical composition and characteristics}

\section{1 $\mathrm{PM}_{1}$ chemical composition}

\subsubsection{Patras}

The estimated mean value of the AMS CE during the wintertime campaign in Patras was $0.77 \pm 0.05$. The density of organics estimated by the same algorithm was $1.45 \pm 0.04 \mathrm{~g} \mathrm{~cm}^{-3}$, which is close to the one for Patras during the summer of $2012\left(1.34 \pm 0.21 \mathrm{~g} \mathrm{~cm}^{-3}\right.$; Kostenidou et al., 2015). The $1 \mathrm{~h}$ averaged $\mathrm{PM}_{1}$ mass concentration (estimated as the sum of the concentration of the AMS and MAAP) varied from a few up to more than $100 \mu \mathrm{g} \mathrm{m}^{-3}$ (Fig. 1). The average $\mathrm{PM}_{1}$ mass concentration was approximately $25 \mu \mathrm{g} \mathrm{m}^{-3}$ (of which $2 \mu \mathrm{g} \mathrm{m}^{-3}$ was BC and $18 \mu \mathrm{g} \mathrm{m}^{-3}$ was $\mathrm{OA}$ ). The $\mathrm{OA}$ mass concentration increased dramatically during the evening hours, reaching levels up to $85 \mu \mathrm{g} \mathrm{m}^{-3}$. The OA also increased during the morning rush hour (07:0010:00 LST), but the corresponding concentrations were less than $25 \mu \mathrm{g} \mathrm{m}^{-3}$. BC concentrations followed closely the variation of $\mathrm{OA}$, with maximum values around $8 \mu \mathrm{g} \mathrm{m}^{-3}$ during nighttime and $4 \mu \mathrm{g} \mathrm{m}^{-3}$ during rush hour in the mornings. The nitrate mass concentration followed a similar trend to OA, with significant peaks occurring both during the morning and evening hours. $\mathrm{PM}_{1}$ nitrate was on average $1 \mu \mathrm{g} \mathrm{m}^{-3}$, but higher values up to $5 \mu \mathrm{g} \mathrm{m}^{-3}$ were measured during the second half of the campaign (from 1 to 5 March). The sulfate concentration was on average $2.6 \mu \mathrm{g} \mathrm{m}^{-3}$ and had smaller fluctuations during the campaign, indicating a different source origin. Chloride's average mass concentration was $0.4 \mu \mathrm{g} \mathrm{m}^{-3}$ but reached values up to $7 \mu \mathrm{g} \mathrm{m}^{-3}$ (4 March). The ammonium concentration followed closely that of sulfate, chloride, and nitrate, indicating the formation of the corresponding ammonium salts.

\subsubsection{Athens}

The mass concentrations of OA, sulfate, nitrate, ammonium, chloride, and $\mathrm{BC}$ are depicted in Fig. 2. The dominant component of $\mathrm{PM}_{1}$ was OA $(61 \%)$. The average AMS $\mathrm{CE}$ during the campaign calculated by the Kostenidou et al. (2007) algorithm was $0.85 \pm 0.23$, and the density of OA was $1.29 \pm 0.21 \mathrm{~g} \mathrm{~cm}^{-3}$. A similar OA density was estimated for Athens during the summer of $2012\left(1.15 \pm 0.36 \mathrm{~g} \mathrm{~cm}^{-3}\right.$; Kostenidou et al., 2015). During the wintertime campaign in Athens, the average total $\mathrm{PM}_{1}$ mass concentration was approximately $10 \mu \mathrm{g} \mathrm{m}^{-3}$ (of which $2 \mu \mathrm{g} \mathrm{m}^{-3}$ was BC), while the hourly maximum value was $140 \mu \mathrm{g} \mathrm{m}^{-3}$ (of which $120 \mu \mathrm{g} \mathrm{m}^{-3}$ was OA). OA was the major component of $\mathrm{PM}_{1}$, with frequent nighttime (after 18:00LST) peaks exceeding $40 \mu \mathrm{g} \mathrm{m}^{-3}$ (Fig. 2). During most campaign days $\mathrm{PM}_{1}$ was lower than $20 \mu \mathrm{g} \mathrm{m}^{-3}$ due to frequent rain and strong winds (Fig. S6). BC during the nighttime was as high as $15 \mathrm{\mu g} \mathrm{m}^{-3}$, while the corresponding morning rush hour maxi- 


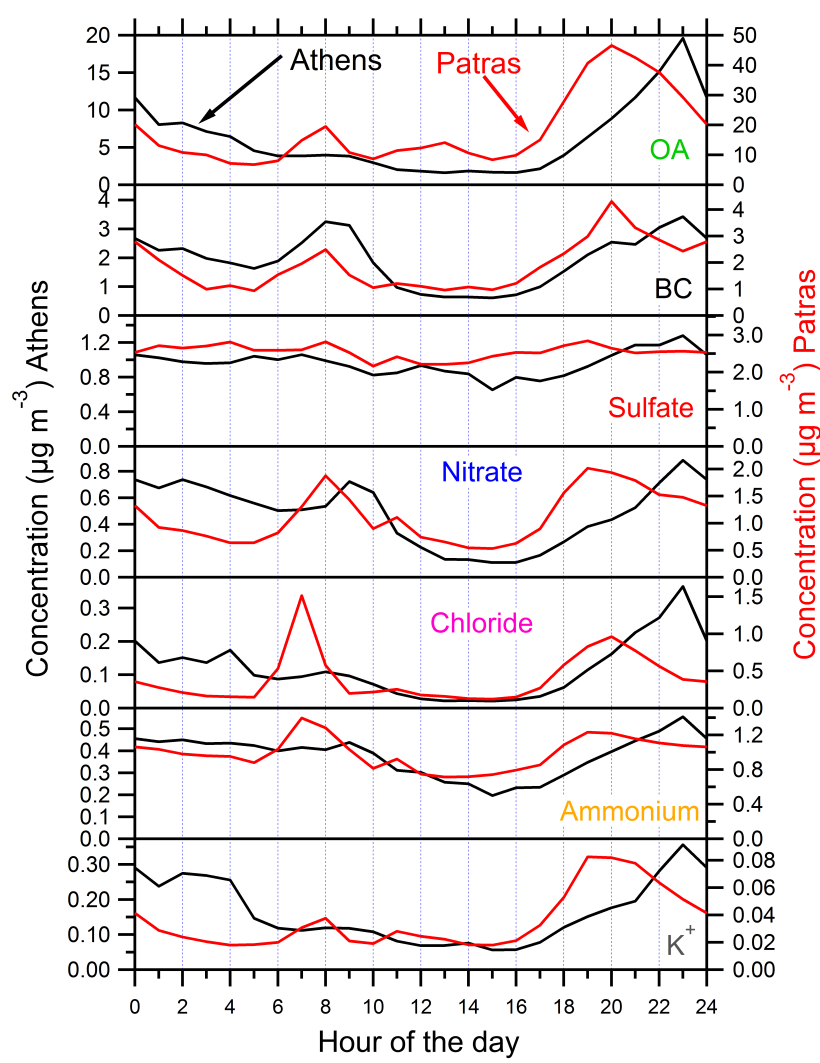

Figure 3. Average diurnal profiles for the main $\mathrm{PM}_{1}$ components during the Athens and Patras campaigns. The concentration of $\mathrm{PM}_{1}$ in Patras is shown on the right $y$ axis.

mum was $8 \mu \mathrm{g} \mathrm{m}^{-3}$. Average ammonium mass concentration was low and around $0.4 \mu \mathrm{g} \mathrm{m}^{-3}$, while the average sulfate was $0.96 \mu \mathrm{g} \mathrm{m}^{-3}$. The nitrate was, on average, $0.48 \mu \mathrm{g} \mathrm{m}^{-3}$, but its maximum values were up to $3.4 \mu \mathrm{g} \mathrm{m}^{-3}$ during nighttime. The correlation between $\mathrm{OA}$ and nitrate was moderate $\left(R^{2}=0.59\right)$.

During the high mass concentration days, and from 18:30 to $02: 30 \mathrm{LST}$, OA was highly correlated $\left(R^{2}=0.95\right)$ with acetonitrile (PTR-MS, $m / z 42, \mathrm{CH}_{3} \mathrm{CN}^{+}$), indicating that biomass burning was the dominant $\mathrm{OA}$ source during these hours. As a reference, during the remaining period (02:30 to 18:30 LST) of the measurements the correlation between OA and acetonitrile deteriorated to $R^{2}=0.54$. During the same periods (18:30 to 02:30 LST), isoprene and furan (PTR-MS, $m / z 69)$ as well as benzene (PTR-MS, $m / z$ 79) were also correlated ( $R^{2}=0.93$ and $R^{2}=0.95$, respectively) with OA and also with each other $\left(R^{2}=0.95\right)$. Isoprene and benzene, both constituents of petrol fuel (Borbon et al., 2001), are emitted to the atmosphere by transportation sources (Langford et al., 2009). However, furan and benzene are also emitted from biomass burning (Gilman et al., 2015; Stockwell et al., 2015; Hatch et al., 2015); therefore, these species may be affected by sources other than just petrol combustion. A detailed anal- ysis of the wintertime Athens VOC data can be found in Kaltsonoudis et al. (2016).

\subsubsection{Diurnal profiles}

The average diurnal profiles of the main $\mathrm{PM}_{1}$ species during the two campaigns are shown in Fig. 3. In Patras, the average $\mathrm{OA}$ and $\mathrm{BC}$ concentrations were characterized by two major peaks during the day (Fig. 3). The first one appeared at around 08:00 LST, coinciding with the morning rush hour traffic, while the second one, which was approximately 2 times higher for both OA and BC, was at 20:00 LST. During the evening, the $\mathrm{OA}$ and $\mathrm{BC}$ concentrations increased considerably, representing almost $90 \%$ of the total $\mathrm{PM}_{1}$ concentration, until around midnight. Sulfate had a relatively flat diurnal profile, while nitrates had two peaks, which coincided with those of $\mathrm{OA}$ and $\mathrm{BC}$. This suggests that nitrate and OA had, at least to some extent, similar sources. The diurnal variation of chloride had a major morning peak at around 07:00 LST. This could be due to two Olympic-size swimming pools, located in a major athletic center, less than $1 \mathrm{~km}$ from the sampling site. The peak coincides with their opening and cleaning hours. The data suggest that the chloride peaks occurred on average an hour earlier (at 07:00 LST) than the corresponding OA peaks (at 08:00 LST). This, coupled with the major differences between known AMS fingerprints for trash burning and the estimated PMF factors here, suggests that trash burning was not a major contributor to the morning chloride peaks. There was also an evening chloride peak (at 20:00 LST) coinciding with those of OA and BC.

In Athens, the OA average diurnal profile was dominated by an evening peak at around 23:00 LST, almost $3 \mathrm{~h}$ later than in the Patras campaign. BC exhibited two major peaks, one in the morning at 08:00 LST, which was attributed to the morning rush hour and another one in the evening at 23:00 LST, coinciding with the OA peak (Fig. 3). This suggests that OA and $\mathrm{BC}$ probably originated from the same source during the night. Nitrate also displayed two peaks, one in the morning (09:00 LST) during the peak traffic hours, and another one in the late evening (23:00 LST). Chloride and ammonium exhibited an evening peak at 23:00 LST, while sulfate had once more a rather flat average diurnal profile.

\subsubsection{Size distributions}

The average size distributions of the different aerosol species (sulfate, organics, ammonium, chloride and nitrate) as a function of the vacuum aerodynamic diameter are depicted in Fig. S7. In Patras, sulfate peaked at $340 \mathrm{~nm}$, whereas OA peaked at $140 \mathrm{~nm}$, implying that the $\mathrm{PM}_{1}$ particles during the sampling period had different composition at different size ranges. The size distribution of ammonium mainly followed that of sulfate, contrary to nitrate, which followed that of OA, suggesting that a major fraction of nitrate was in the form of organonitrates (ONs). In Athens, the sulfate size distribution 
peaked at $310 \mathrm{~nm}$, close to the value during the Patras campaign, whereas OA peaked at $250 \mathrm{~nm}$. Nitrate peaked at the same diameter $(250 \mathrm{~nm})$ as OA.

\subsubsection{Organonitrates}

The $\mathrm{NO}_{2}^{+} / \mathrm{NO}^{+}$ratio was used in order to estimate the concentration of particulate ONs (Farmer et al., 2010; Fry et al., 2009). Typical values of $\mathrm{NO}_{2}^{+} / \mathrm{NO}^{+}$for ammonium nitrate $\left(\mathrm{NH}_{4} \mathrm{NO}_{3}\right)$ have been reported to be in the range from 0.33 to 0.85 (Alfarra et al., 2006; Cottrell et al., 2008; Fry et al., 2009), and those for organonitrates from 0.07 to 0.1 (Fry et al., 2009; Hao et al., 2014). ONs are also known to be components of SOA (Farmer et al., 2010; Fry et al., 2009; Ng et al., 2008).

In this work, the measured $\mathrm{NO}_{2}^{+} / \mathrm{NO}^{+}$ratio for pure $\mathrm{NH}_{4} \mathrm{NO}_{3}$ in Athens and Patras was equal to 0.59 and 0.75 , respectively. The fraction of ONs to the total nitrate was estimated using the equation suggested by Farmer et al. (2010). The minimum observed $\mathrm{NO}_{2}^{+} / \mathrm{NO}^{+}$ratio during each campaign was 0.04 for Athens and 0.055 for Patras.

The average $\mathrm{ON}$ fraction of the total nitrate in Athens and Patras was $42 \pm 25$ and $45 \pm 14 \%$, respectively. In Athens, during nighttime (17:00 until 03:00 LST, for the whole dataset), the average ON fraction was $38 \pm 20 \%$. During nights (from 20:00 until 03:00 LST) with enhanced OA plumes exceeding $15 \mu \mathrm{g} \mathrm{m}^{-3}$, the $\mathrm{ON}$ fraction was lower and equal to $19 \pm 10 \%$. This suggests that during biomass burning events $\mathrm{ON}$ is not the major component of nitrate. In Patras, the average ON fraction for the whole campaign was $45 \pm 14 \%$. During evening OA peaks (16:00 until 24:00 LST, for the whole dataset) the average ON fraction was $44 \pm 13 \%$.

\subsection{OA elemental ratios}

The atomic oxygen-to-carbon ratio $(\mathrm{O}: \mathrm{C})$ of $\mathrm{OA}$ is a useful metric of its extent of oxygenation, which increases as the aerosol is exposed to atmospheric oxidants (Murphy et al., 2011; Sage et al., 2008).

In Patras, the average $\mathrm{O}: \mathrm{C}$ ratio was $0.42 \pm 0.09$ following the Canagaratna et al. (2015) approach, while the hydrogen-to-carbon ratio $(\mathrm{H}: \mathrm{C})$ was $1.71 \pm 0.06$. For comparison with the literature, the corresponding values following the Aiken et al. (2008) approach were $0.33 \pm 0.07$ and $\mathrm{H}: \mathrm{C}=1.53 \pm 0.05$. The corresponding time series are shown in Figs. S8 and S9. In Athens, the average O:C ratio based on the Canagaratna approach was $0.32 \pm 0.11$ $(0.26 \pm 0.09$ for the Aiken approach), while the $\mathrm{H}: \mathrm{C}$ was $1.72 \pm 0.11(1.59 \pm 0.11$ using the Aiken approach). The temporal evolution of these ratios is also depicted in Figs. S8 and S9. The relatively low average values of $\mathrm{O}: \mathrm{C}$ for both Athens and Patras are consistent with the OA being dominated by primary emissions (Allan et al., 2010). The corresponding $\mathrm{O}: \mathrm{C}$ ratios during summertime for Athens and $\mathrm{Pa}$ -

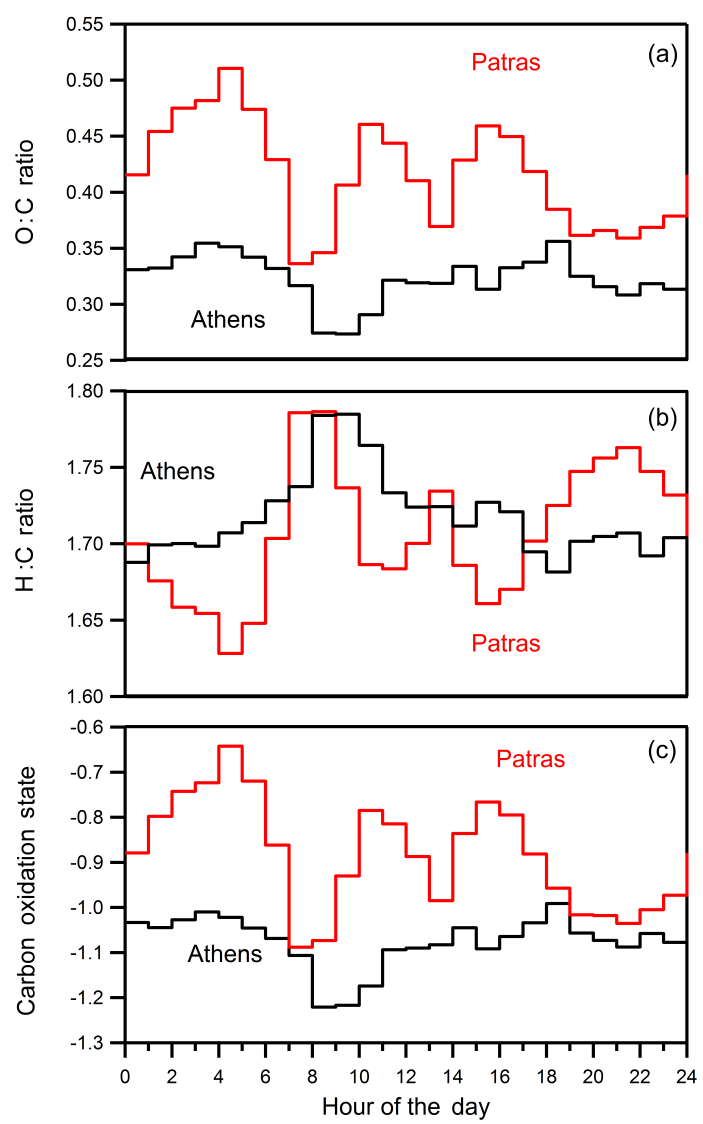

Figure 4. The diurnal profile of (a) the $\mathrm{O}: \mathrm{C}$ ratio, (b) the $\mathrm{H}: \mathrm{C}$ ratio, and (c) the $\mathrm{OS}_{\mathrm{C}}$ in Athens (black) and Patras (red). The ratios have been calculated following the Canagaratna et al. (2015) approach.

tras were approximately 0.2 units higher (Kostenidou et al., 2015).

Another metric of the extent of oxidation of atmospheric $\mathrm{OA}$ is the average carbon oxidation state $\mathrm{OS}_{\mathrm{C}}$, a value that increases upon oxidation (Kroll et al., 2011). The $\mathrm{OS}_{\mathrm{C}}$ for both cities was calculated by applying the equation proposed by Kroll et al. (2011):

$\mathrm{OS}_{\mathrm{C}}=2(\mathrm{O}: \mathrm{C})-(\mathrm{H}: \mathrm{C})$.

In Patras, $\mathrm{OS}_{\mathrm{C}}$ was $-0.88 \pm 0.19$, ranging from -1.40 to -0.37 , while in Athens the $\mathrm{OS}_{\mathrm{C}}$ was on average $-1.08 \pm 0.28$, varying from -1.8 to 0.98 (Fig. S10).

The average diurnal profiles of $\mathrm{O}: \mathrm{C}, \mathrm{H}: \mathrm{C}$, and $\mathrm{OS}_{\mathrm{C}}$ for both cities are shown in Fig. 4. The changes in the $\mathrm{O}: \mathrm{C}$ ratio were in the opposite direction from those of the $\mathrm{H}: \mathrm{C}$. The decreases in $\mathrm{O}: \mathrm{C}$ and the corresponding increases in $\mathrm{H}: \mathrm{C}$ during the morning and midday rush hours were due to the fresh traffic emissions. The corresponding changes during the evening were due to the biomass burning activity. Background $\mathrm{OA}$ dominated the observed $\mathrm{O}: \mathrm{C}$ ratio during the rest of the day. In Patras, the $\mathrm{O}: \mathrm{C}$ ratio increased significantly during the late night hours (02:00 to 07:00 LST), during the 
morning (peak at around 10:00 LST), and also at around 15:00 in the afternoon. The primary emissions, mainly from traffic, led in this case too to reductions of the average $\mathrm{O}: \mathrm{C}$ and increases in $\mathrm{H}: \mathrm{C}$ during the corresponding peak periods. In Athens, the $\mathrm{O}: \mathrm{C}$ increased during the early morning hours and after 10:00 LST. The diurnal profiles of $\mathrm{OS}_{\mathrm{C}}$ were similar to those of $\mathrm{O}: \mathrm{C}$. The mean organic-aerosol-to-organiccarbon ratio $(\mathrm{OA} / \mathrm{OC})$ for Athens was $1.50 \pm 0.1$ and varied between 1.2 and 2.2 during the measurement period, while in Patras it was $1.59 \pm 0.1$, ranging from 1.3 to 2 .

\section{Source apportionment of $\mathrm{OA}$}

Positive matrix factorization (Paatero and Tapper, 1994; PMF) was applied to the HR-ToF-AMS organic mass spectra ( $m / z$ up to 200), using the PMF Evaluation Tool (PET; Lanz et al., 2008; Ulbrich et al., 2009). The selection of the PMF solution was based on the comparison of the spectra of the calculated factor to those of the literature, their physical meaning, their diurnal cycles, the correlation of the factor's resulting time series with each other and other variables (usually concentrations of other pollutants), and finally the PMFmodel residuals. For both campaigns, biomass burning was identified as the dominant source of OA and was responsible for $40-60 \%$ of the total OA. The results for both cities are summarized in Fig. 5.

For Patras, PMF solutions with one to seven factors were investigated. In the three-factor solution a BBOA, a HOA, and an OOA factor were obtained, with BBOA being the dominant component of OA. Moving to a four-factor solution, a second factor related to biomass burning was obtained quite different from the other, with a noticeable difference in both fractions of $m / z 44$ and $60\left(f_{44}\right.$ and $\left.f_{60}\right)$, and a high value of theta angle $\left(\theta=32^{\circ}\right)$ between the mass spectra. In the five-factor solution, a COA factor was resolved. The increase in the number of factors up to this point was accompanied by a reduction in the residuals. On the other hand, the model residuals for the six- and seven-factor solutions were almost identical to those of the five-factor solution. Thus, a five-factor solution was selected for the specific dataset (Supplement Sect. S7, Figs. S11-S17). The two biomass-burning-related OA factors (BBOA-I and BBOA-II) dominated the measured OA composition (almost $60 \%$ ) during the evenings. The OOA factor accounted on average for $18 \%$ of the OA, while HOA and COA represented 12 and $11 \%$, respectively. The BBOA, HOA, and COA factors correspond to primary sources, whereas the OOA corresponds to atmospheric processing (secondary OA). The PMF factors' time series and contribution to $\mathrm{PM}_{1} \mathrm{OA}$ are depicted in Fig. 6.

In Athens, the PMF model resolved four sources of OA: BBOA (43\%), OOA (24\%), HOA (17\%), and COA (16\%). Their time series and contribution to $\mathrm{PM}_{1}$ organic aerosol are depicted in Fig. 7. A PMF analysis with up to six fac- tors was performed (Sect. S7, Figs. S18-S24). By extending the solution from a four- to a five-factor solution, another biomass-burning-related (BBOA-II, $14 \%$ of OA) factor was generated in addition to the first one (BBOA-I, $39 \%$ of OA). The PMF residuals in this case decreased slightly and only for the first 2 days of the campaign (Fig. S19). For this solution, the mass concentrations of OOA ( $20 \%$ of OA), HOA ( $13 \%$ of $\mathrm{OA})$, and COA ( $14 \%$ of OA) were pretty similar to those in the four-factor solution. The five-factor solution was not used because the two biomass burning factors resembled each other $\left(\theta=15^{\circ}\right)$ and had similar diurnal profiles. The correlations between the BBOA-I and BBOA-II factors in Athens and VOCs as measured by the PTR-MS are shown in Table S1 in the Supplement.

Figure 8 summarizes the mass spectra of the identified OA components. Each one of these is analyzed in the following sections.

\subsection{Biomass-burning-related organic aerosol}

\subsubsection{Patras}

The selected five-factor PMF solution for Patras included two BBOA-like factors, named BBOA-I and BBOA-II. Both of these factors had significant contributions at the $\mathrm{m} / \mathrm{z}$ values $60\left(\mathrm{C}_{2} \mathrm{H}_{4} \mathrm{O}_{2}^{+}\right)$and $73\left(\mathrm{C}_{3} \mathrm{H}_{5} \mathrm{O}_{2}^{+}\right)$, which are typical fragments of levoglucosan, a marker for biomass burning (Aiken et al., 2009; Alfarra et al., 2007; Cubison et al., 2011; Heringa et al., 2011). However, their mass spectra were quite different $\left(\theta=32^{\circ}\right)$, and their time series had a rather low correlation with each other $\left(R^{2}=0.2\right)$. The two BBOA factors represented $60 \%$ of the OA on average during the campaign, with their contribution rising to $90 \%$ or so during the night hours (18:00 to 24:00 LST). The fraction of $m / z 60$, characteristic of levoglucosan, was $f_{60}=0.025$ in BBOA-I and much lower, $f_{60}=0.009$, in BBOA-II.

The BBOA-I factor was by far the most important component of $\mathrm{PM}_{1} \mathrm{OA}(40 \%)$ in Patras, with a mean concentration of $7 \mu \mathrm{g} \mathrm{m}^{-3}$. BBOA-I levels increased after 16:00 LST, reaching values exceeding $35 \mu \mathrm{g} \mathrm{m}^{-3}$ at around 20:00 LST (Fig. 6). During the evening periods it represented up to $75 \%$ of the total OA while during the day its concentration was always less than $5 \mu \mathrm{g} \mathrm{m}^{-3}$. The BBOA-I factor correlated well with the AMS $\mathrm{K}^{+}\left(R^{2}=0.76\right)$ and had modest correlations with the total nitrate measured by the AMS $\left(R^{2}=0.55\right), \mathrm{CO}$ $\left(R^{2}=0.40\right)$, and $\mathrm{BC}\left(R^{2}=0.27\right)$. The corresponding coefficient of determination between the BBOA-I and chloride was low and equal to 0.16. Also, BBOA-I correlated better $\left(R^{2}=0.31\right)$ with ONs than BBOA-II $\left(R^{2}=0.09\right)$, implying that BBOA-I was a more significant source of ONs in Patras.

BBOA-II was the second biomass-burning-related factor, contributing $19 \%$ to the $\mathrm{PM}_{1} \mathrm{OA}$ in Patras. Its contribution was higher during the first days, when it represented up to $40 \%$ of the total OA. Its mean value for the whole campaign was equal to $3.3 \mu \mathrm{g} \mathrm{m}^{-3}$, and its hourly maximum 
Athens

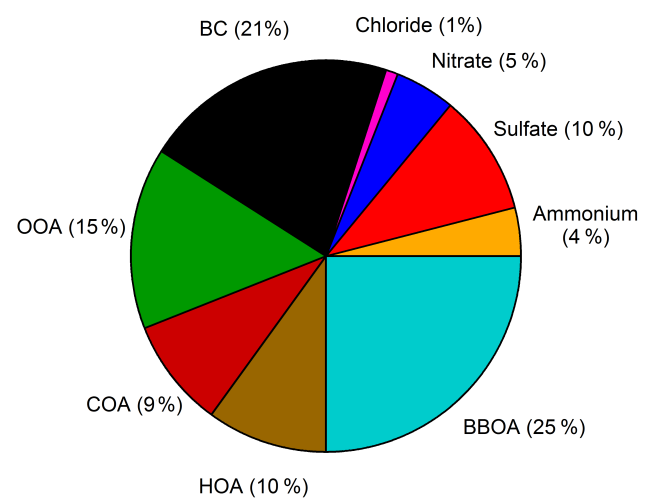

Patras

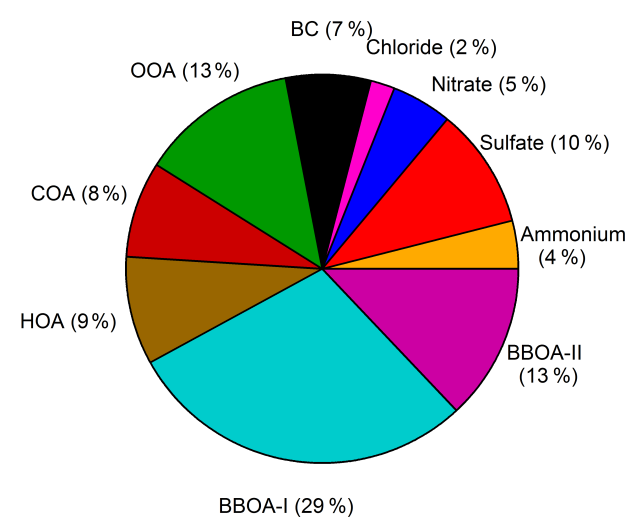

Figure 5. Average $\mathrm{PM}_{1}$ composition and organic source apportionment for Athens and Patras. The average $\mathrm{PM}_{1}$ for $\mathrm{Athens}$ was $10 \mu \mathrm{g} \mathrm{m}^{-3}$, while for Patras it was $25 \mu \mathrm{g} \mathrm{m}{ }^{-3}$.

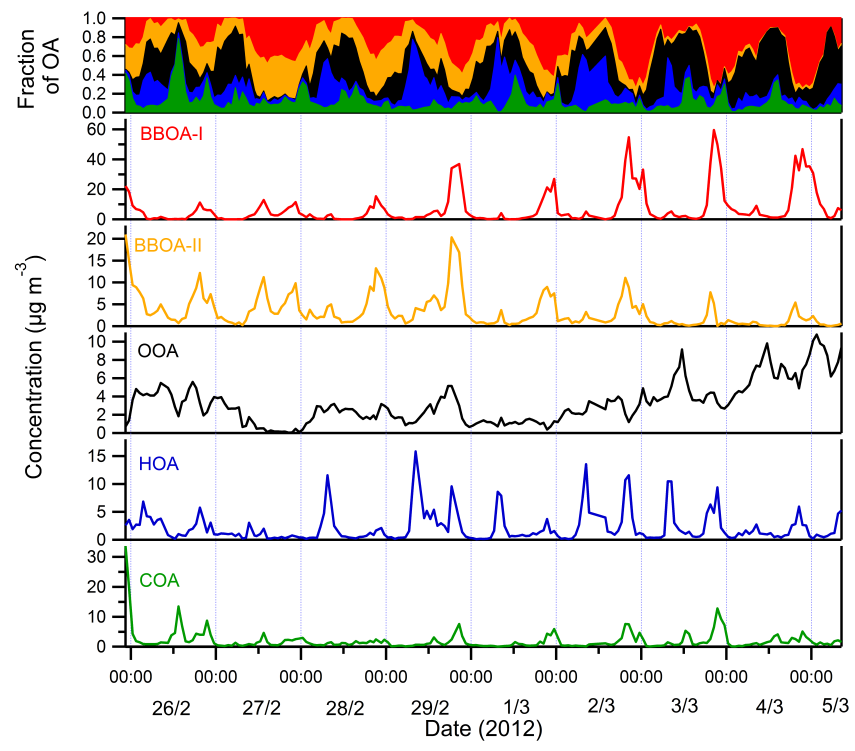

Figure 6. Fractional contribution to $\mathrm{OA}$ and time series of the PMF factors during the Patras campaign.

value almost $21 \mu \mathrm{g} \mathrm{m}^{-3}$. BBOA-II correlated poorly with all the major AMS species $\left(R^{2}<0.1\right)$ and modestly with $\mathrm{BC}$ $\left(R^{2}=0.26\right)$. The $R^{2}$ between BBOA-II and the AMS chloride was 0.02. The low correlations of both BBOA-I and BBOA-II with chloride did not support the link between one of these factors and trash burning or chloride. Its diurnal cycle exhibited two evening peaks, one at 18:00 (LST) and a smaller one at 22:00 (LST). Its mean mass concentration during daytime was less than $3 \mu \mathrm{g} \mathrm{m}^{-3}$ and close to the corresponding one of BBOA-I.

The BBOA-I and BBOA-II spectra for Patras are shown in Fig. 8. The BBOA-I spectrum had strong signals at $m / z 29$ $\left(\mathrm{CHO}^{+}\right), 43\left(\mathrm{C}_{2} \mathrm{H}_{3} \mathrm{O}^{+}\right), 60\left(\mathrm{C}_{2} \mathrm{H}_{4} \mathrm{O}_{2}^{+}\right)$, and $73\left(\mathrm{C}_{3} \mathrm{H}_{5} \mathrm{O}_{2}^{+}\right)$,

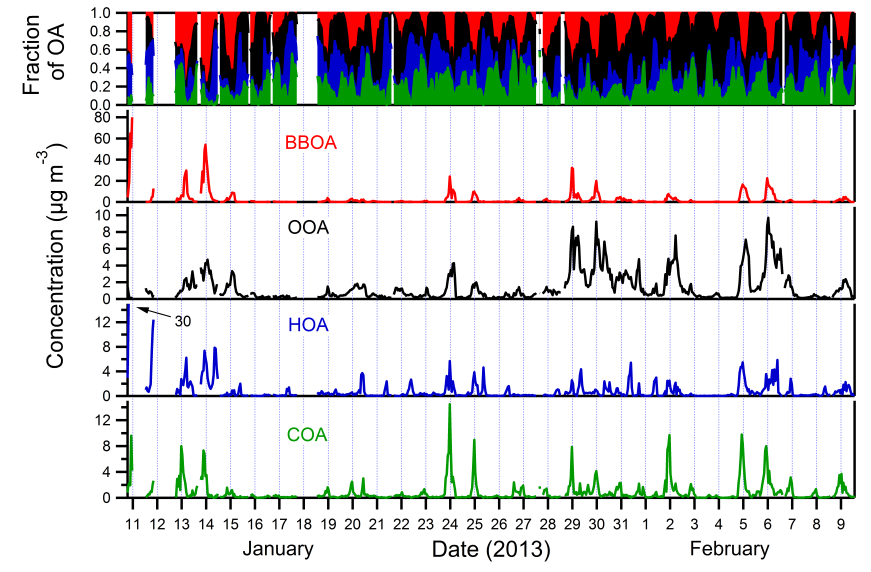

Figure 7. The hourly fractional contribution to OA and time series of the PMF factors during the Athens campaign. During the first day, HOA reached levels up to $30 \mu \mathrm{g} \mathrm{m}^{-3}$.

while the spectrum of BBOA-II was characterized by lower signal in $m / z$ values attributed to fresh OA - like 43,55 , and 57 - and a stronger signal at $m / z 44$, which is usually related to aged organic aerosol ( $f_{44}$ was equal to 0.043 ). The contribution of $m / z 60$ in the BBOA-II spectrum was $67 \%$ lower compared than the BBOA-I spectrum, suggesting the evaporation of levoglucosan. There was also a prominent peak at $m / z 39$, as well as a peak at $m / z 91$, which can be indicative of aromatic species such as benzyl ions (Allan et al., 2003, 2004; Trainer et al., 2012). This $m / z 91$ peak was also present in the spectrum of the BBOA factor from the burning of olive tree branches in Greece (Kostenidou et al., 2013). In general, people in Greece use multiple fuel types that can vary from region to region due to the local availability of the corresponding type of biomass. For example, in Patras softwood (pine, fir, etc.) or hardwood (oak, beech, olive tree) is 

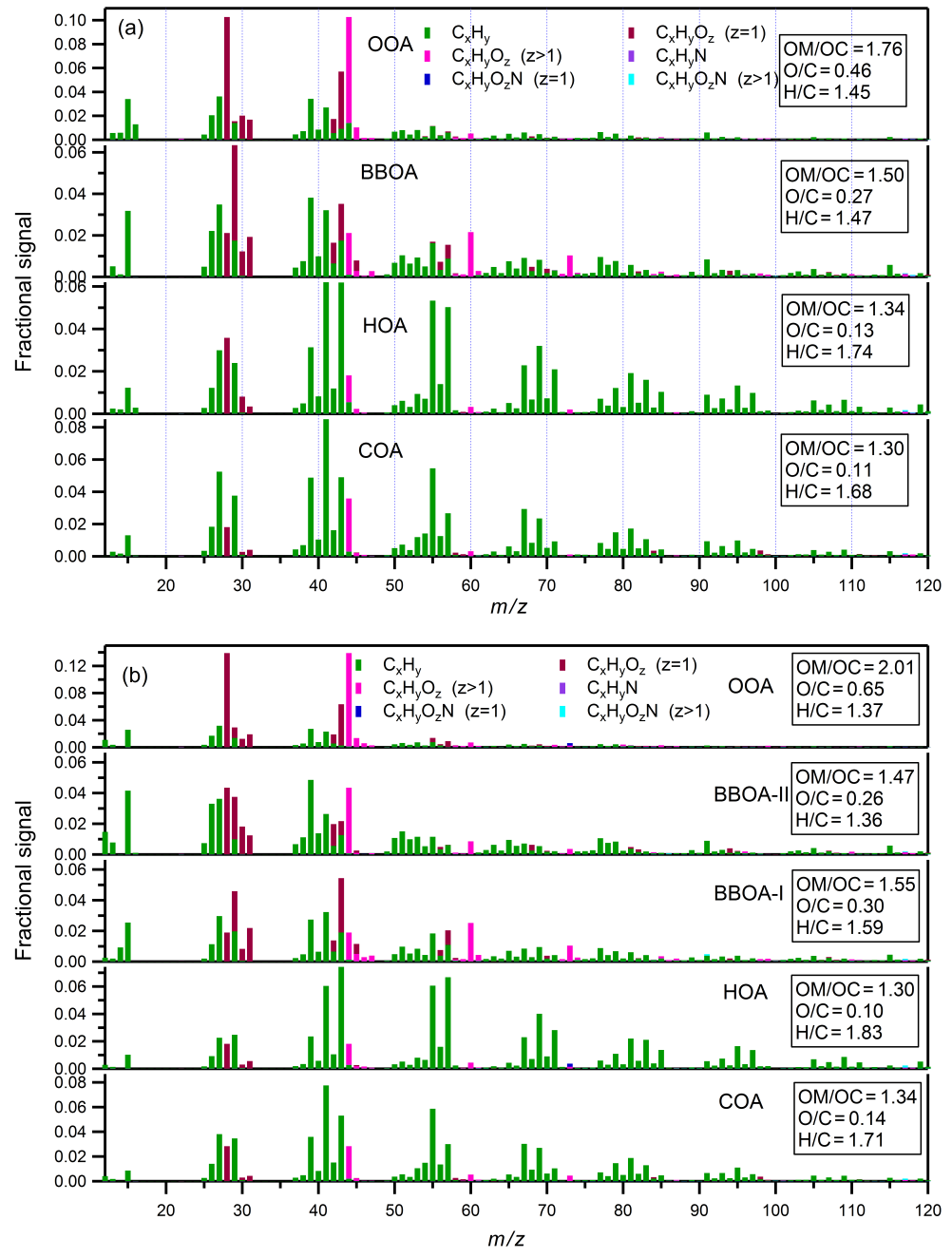

Figure 8. High-resolution AMS mass spectra for the factors in (a) Athens and (b) Patras.

used. In Athens, people burn mainly pine and fir. The $\mathrm{O}: \mathrm{C}$ ratio of BBOA-I was 0.3, while that of BBOA-II was equal to 0.26 . The corresponding OA / OC ratios were 1.55 and 1.47. These two factors could correspond to different degrees of aging of the BBOA, different types of combustion or fuel, or a combination of these mechanisms.

Another explanation is that the two BBOA factors in $\mathrm{Pa}$ tras could correspond to different fuel types, with one of them including trash burning. To test this hypothesis, the spectra of the BBOA factors were compared to those of OA resulting from paper and plastic burning (Mohr et al., 2009). The trash burning AMS spectra were completely different from the BBOA spectra in this study, with angles exceeding $45^{\circ}$. This suggests that trash burning cannot be the main source of any of the two BBOA factors in Patras.

Recent work has shown that the emissions of nitrogencontaining organic compounds (such as acetonitrile) strongly depend on the composition of the fuel (Coggon et al. 2016). Fuels containing low amounts of nitrogen (e.g., wood) emit lower amounts of $\mathrm{N}$-organics than fuels containing large amounts of nitrogen (e.g., grasses, the boughs of trees). The same behavior has been observed for inorganic nitrogen gasses, such as ammonia $\left(\mathrm{NH}_{3}\right)$ and $\mathrm{NO}_{x}$ (e.g., Burling et al., 2010). Consequently, if different fuels were burned, then different amounts of ON could be formed due to differences in the amount of $\mathrm{NO}_{x}$ emitted or, perhaps, differences in emissions of primary organic nitrogen.

The BBOA factor in ambient studies is believed to represent an average of the emissions of all fuel types. However, the corresponding emissions should have either a different temporal or a spatial profile in order to be separated by PMF. Given that residential biomass burning, in a city like Patras, is due to tens of thousands of individual sources (fireplaces, wood stoves, etc.) spread all over the city following a similar burning schedule on average, it is difficult to explain how PMF would be able to separate the BBOA from different fuel types. However, there are other potential explanations (e.g., different areas of the city using different fuel types and the 
emissions arriving at the site at different times) that could involve the use of different fuel types. Therefore, even if the support of this hypothesis is rather weak, it cannot be eliminated as a potential explanation.

\subsubsection{Athens}

The BBOA factor contributed almost half (43\%) of the OA in Athens. BBOA reached hourly levels up to $80 \mu \mathrm{g} \mathrm{m}^{-3}$ during the evening of the first day of the campaign, which was the coldest day during the period of the measurements. The average BBOA concentration was $2.3 \mu \mathrm{g} \mathrm{m}^{-3}$. However, when meteorological conditions were favorable (no precipitation), BBOA sharply increased after 17:00 LST, frequently reaching values greater than $20 \mu \mathrm{g} \mathrm{m}^{-3}$ at approximately 23:00 LST (Fig. 7). This peak was observed a few hours later in Athens than in Patras, potentially due to the different lifestyles in the two cities. A peak was also observed between 01:00 and 04:00 LST. A similar peak was present in the diurnal profile of the AMS $\mathrm{K}^{+}$(Fig. S25), implying a common source for both. This could be due to either morning combustion or vertical mixing. During the rest of the day the BBOA levels remained lower than $1 \mu \mathrm{g} \mathrm{m}^{-3}$.

BBOA and gas-phase acetonitrile (PTR-MS, $m / z 42$, $\left.\mathrm{CH}_{3} \mathrm{CN}^{+}\right)$were strongly correlated $\left(R^{2}=0.81\right)$. BBOA was also well correlated with AMS chloride $\left(R^{2}=0.88\right)$. Moderate correlations were observed with $\mathrm{CO}\left(R^{2}=0.58\right)$, AMS $\mathrm{K}^{+}\left(R^{2}=0.40\right), \mathrm{BC}\left(R^{2}=0.33\right)$, and $\mathrm{NO}_{x}\left(R^{2}=0.29\right)$. High correlations were observed between BBOA and 2methyl-3-buten-2-ol (MBO; PTR-MS, $m / z 87 ; R^{2}=0.93$ ), which is related to emissions from pine trees (Vlasenko et al., 2009), isoprene and furan at $m / z 69\left(\mathrm{C}_{5} \mathrm{H}^{+}\right.$and $\left.\mathrm{C}_{4} \mathrm{H}_{5} \mathrm{O}^{+} ; R^{2}=0.88\right)$, methacrolein and methyl vinyl ketone $\left(\mathrm{C}_{4} \mathrm{H}_{7} \mathrm{O}^{+}\right)$at $m / z 71\left(R^{2}=0.81\right)$, and $m / z 85$ (among possible candidates, ethyl vinyl ketone; $R^{2}=0.9$ ). These results are consistent with previous studies suggesting that wood burning is major source of biogenic VOCs (Akagi et al., 2011). The correlation between the BBOA factor in Athens and VOCs as measured by the PTR-MS are shown in Table 1.

The AMS spectrum of BBOA in Athens had prominent peaks at $m / z 39\left(\mathrm{C}_{2} \mathrm{H}_{2}^{+}\right), 60\left(\mathrm{C}_{2} \mathrm{H}_{4} \mathrm{O}_{2}^{+}\right)$, and $73\left(\mathrm{C}_{3} \mathrm{H}_{5} \mathrm{O}_{2}^{+}\right)$. $\mathrm{A}$ high contribution to the total organic signal was present at $m / z 29$ mostly due to $\mathrm{CHO}^{+}$, consistent with the findings of Alfarra et al. (2007). The BBOA HR spectra, with the dominant ion families, are represented in Fig. 8. The BBOA O : C ratio in Athens was 0.27.

\subsubsection{BBOA factor comparisons}

The mass spectra of BBOA in Athens and BBOA-I in Patras shared some similarities $\left(\theta=14^{\circ}\right)$, with the main differences at $m / z 29,39,43,57,60$, and 73 (Fig. S26). Their $f_{44}$ were close to each other (0.02). The mass spectra of BBOA in Athens and BBOA-II in Patras were quite different $\left(\theta=25^{\circ}\right)$.
Their major differences were present at $m / z$ values 26,28 , 29, 39, 41, 43, 44, 55, 57, 60, and 73 .

Residential burning was the main BBOA source in Greece during the present study. The BBOA-I spectrum in Patras was similar to that of residential wood combustion in Fresno $\left(\theta=11^{\circ}\right.$; Ge et al., 2012) and to BBOA from the MILAGRO (Megacity Initiative: Local and Global Research Observations) campaign $\left(\theta=14^{\circ}\right.$; Aiken et al., 2009; Fig. S27). The BBOA-II spectrum in Patras was quite different (angles $\theta$ exceeding $24^{\circ}$ ) than those in the literature (Fig. S28). All types of wood burning were included in the comparisons, for completeness. Comparisons of the spectrum of BBOA-II with those of OOA factors revealed lower theta values (less than $30^{\circ}$; Fig. S29). This indicates a moderate resemblance of BBOA-II and chemically aged aerosol. The theta angle of the BBOA-II with the spectra of OOA in Fresno (Ge et al., 2012), New York (Sun et al., 2012), and semi-volatile OOA (SV-OOA) from SOAR (Study of Organic Aerosols at Riverside; Docherty et al., 2011) was lower than $30^{\circ}$.

The Athens BBOA spectrum was similar $\left(\theta=12^{\circ}\right)$ to that of the BBOA factor in Fresno (Ge et al., 2012) and shared some similarities with spectra from the burning of ponderosa pine duff $\left(\theta=21^{\circ}\right)$ and the Alaska core Tundra duff $(\theta=$ $22^{\circ}$ ) during FLAME-I (Fire Lab At Missoula Experiment, Phase 1). For the rest of the database spectra, the theta angle values exceeded $25^{\circ}$ (Fig. S30).

\subsection{Oxygenated organic aerosol}

OOA is often considered as a surrogate for secondary OA due to both local production processes and long-range transport of chemically aged OA from other areas.

\subsubsection{Patras}

The OOA factor dominated daytime OA, and its mass concentration increased during the last days of the campaign. The mean OOA was $3.2 \mu \mathrm{g} \mathrm{m}^{-3}$, while its hourly maximum value, around midday of $5 \mathrm{March}$, was equal to $10.8 \mu \mathrm{g} \mathrm{m}^{-3}$. It represented $18 \%$ of the OA on average. For comparison, during summertime at the same area, OOA accounted for almost $80 \%$ of OA due to the higher photochemical activity (Kostenidou et al., 2015). The average diurnal pattern of OOA was relatively stable (Fig. 9) with small peaks during the morning (08:00 and 11:00 LST) and slightly lower values after 18:00 LST. This pattern is consistent with a regional source and domination by atmospheric transport rather than local sources and processes. The OOA was correlated reasonably well with particulate ammonium $\left(R^{2}=0.61\right)$ and sulfate $\left(R^{2}=0.56\right)$, while its correlation with nitrate was moderate $\left(R^{2}=0.38\right)$.

\subsubsection{Athens}

In contrast to other measurement datasets in Athens, in which two OOA types were obtained by PMF (a very oxidized OA, 
Table 1. Coefficient of determination $R^{2}$ between the OA factors in Athens and VOCs.

\begin{tabular}{lrrrr}
\hline$m / z$ & BBOA & HOA & COA & OOA \\
\hline 42 (acetonitrile) & 0.81 & 0.67 & 0.35 & 0.20 \\
43 (multiple species) & 0.71 & 0.59 & 0.30 & 0.19 \\
47 (formic acid) & 0.43 & 0.49 & 0.11 & 0.06 \\
59 (acetone, glyoxal) & 0.70 & 0.61 & 0.31 & 0.25 \\
61 (acetic acid) & 0.52 & 0.33 & 0.18 & 0.14 \\
69 (isoprene, furan) & 0.88 & 0.63 & 0.31 & 0.14 \\
71 (methyl vinyl ketone, methacrolein) & 0.81 & 0.74 & 0.32 & 0.13 \\
73 (methyl ethyl ketone) & 0.75 & 0.61 & 0.31 & 0.21 \\
75 (hydroxyacetone) & 0.69 & 0.41 & 0.24 & 0.09 \\
79 (benzene) & 0.71 & 0.70 & 0.31 & 0.16 \\
81 (terpenes) & 0.85 & 0.63 & 0.30 & 0.15 \\
85 (ethyl vinyl ketone) & 0.90 & 0.68 & 0.34 & 0.14 \\
87 (2-methyl-3-buten-2-ol, C5, methacrylic acid) & 0.93 & 0.59 & 0.33 & 0.15 \\
93 (toluene) & 0.37 & 0.54 & 0.18 & 0.09 \\
95 (2 vinyl furan, phenol) & 0.43 & 0.36 & 0.12 & 0.02 \\
99 (hexenal) & 0.87 & 0.58 & 0.34 & 0.21 \\
101 (isoprene hyperoxides) & 0.71 & 0.48 & 0.25 & 0.12 \\
105 (styrene) & 0.54 & 0.55 & 0.19 & 0.09 \\
107 (xylenes) & 0.47 & 0.65 & 0.23 & 0.11 \\
113 (chlorobenzene) & 0.80 & 0.53 & 0.31 & 0.21 \\
115 (heptanal) & 0.66 & 0.48 & 0.22 & 0.13 \\
121 (C9 aromatics) & 0.47 & 0.66 & 0.21 & 0.10 \\
129 (octanal, naphthalene) & 0.70 & 0.73 & 0.21 & 0.07 \\
135 (C10 aromatics) & 0.50 & 0.64 & 0.21 & 0.12 \\
137 (monoterpenes) & 0.71 & 0.52 & 0.25 & 0.19 \\
139 (nopinone) & 0.67 & 0.41 & 0.22 & 0.18 \\
151 (pinonaldehyde) & 0.32 & 0.26 & 0.09 & 0.06 \\
163 (C12 aromatics) & 0.38 & 0.27 & 0.10 & 0.12 \\
\hline & & & & \\
& & & \\
& & &
\end{tabular}

V-OOA, and a moderately oxygenated, M-OOA; Kostenidou et al., 2015), only one type was clearly present in Athens during the winter. The OOA factor dominated OA during the daytime and its mass concentration increased after 28 January, when air masses originated from the Balkans and not from the Mediterranean Sea (Sects. S3 and S4). The average OOA concentration was $1.3 \mu^{-3} \mathrm{~m}^{-3}$, with a maximum value of $9.7 \mu \mathrm{g} \mathrm{m}^{-3}$. OOA was correlated with $\mathrm{NH}_{4}^{+}\left(R^{2}=0.65\right)$, $\mathrm{SO}_{4}^{2-}\left(R^{2}=0.58\right)$, and $\mathrm{NO}_{3}^{-}\left(R^{2}=0.67\right)$. The average diurnal concentration of OOA decreased smoothly during morning hours, reaching a minimum at around 15:00 LST, and increased again during the afternoon and evening, peaking at midnight (Fig. 9). Biomass-burning-related VOCs such as monoterpenes $\left(\mathrm{C}_{10} \mathrm{H}_{16}\right)$ and isoprene $\left(\mathrm{C}_{5} \mathrm{H}_{8}\right)$ can react with $\mathrm{NO}_{3}$ radicals (Hodzic et al., 2009; $\mathrm{Ng}$ et al., 2008; Rollins et al., 2009), resulting in nighttime SOA production. In the case of Athens, the increase of OOA during the night is accompanied by increases in mostly inorganic nitrate, with a relatively small contribution of organic nitrate. This does not support the hypothesis that the OOA increase is due to the production of SOA from reactions of the biomass burning emissions with nitrate radicals.
In Patras, the wintertime OOA $\mathrm{O}: \mathrm{C}$ ratio was 0.65 (Fig. 10). For comparison reasons, the $\mathrm{O}: \mathrm{C}$ ratio for $\mathrm{V}-\mathrm{OOA}$, M-OOA, and biogenic OOA (b-OOA) during the summer campaign of 2012 in Patras was $0.81,0.54$, and 0.48 , respectively (Kostenidou et al., 2015). In Athens, the $\mathrm{O}: \mathrm{C}$ ratio for OOA during the winter of 2013 was equal to 0.47 (Fig. 10). The corresponding values of $\mathrm{O}: \mathrm{C}$ during summertime in Athens for V-OOA and M-OOA were 0.68 and 0.56 , respectively (Kostenidou et al., 2015).

\subsubsection{OOA factor comparisons}

Both OOA spectra were characterized by a strong peak at $m / z 44$ (mostly due to $\mathrm{CO}_{2}^{+}$), related to the thermal decomposition of organic acids (Alfarra et al., 2004); a lower one at $m / z 43$ (mostly due to $\mathrm{C}_{2} \mathrm{H}_{3} \mathrm{O}^{+}$); and another one at $m / z 28$, all consistent with the OOA spectra reported in other studies. The OOA spectra in the two cities were quite similar to each other $\left(\theta=11^{\circ}\right)$, with the greatest differences at $m / z$ values 28 and 44. The OOA in Athens exhibited lower $f_{44}(0.12)$ than the one in Patras (0.15).

The spectrum of OOA in Patras was quite similar to the first two factors named OOA-a and OOA-b by the authors $\left(\theta=7^{\circ}\right)$ for the Po Valley (Saarikoski et al., 2012), the sum- 


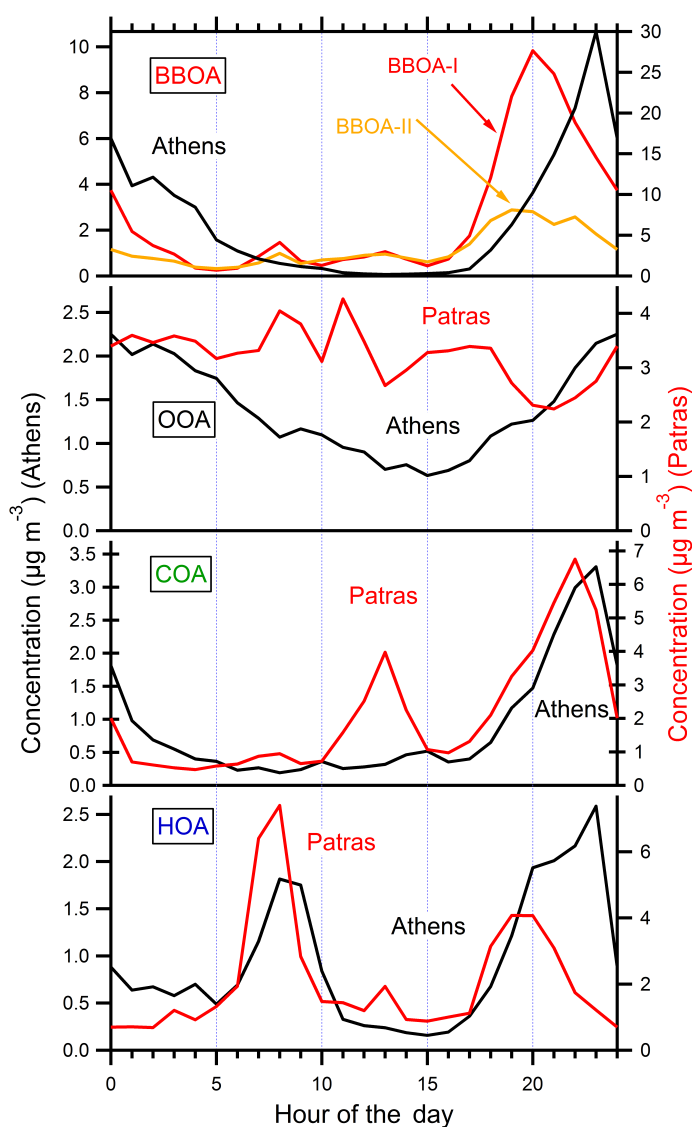

Figure 9. Diurnal profiles of the PMF factors in Athens (black) and Patras (red-yellow). On the left $y$ axis are the concentrations of Athens' PMF factors, while on the right $y$ axis are those of $\mathrm{Pa}$ tras.

mertime spectra of M-OOA in Athens and Patras $\left(\theta=10^{\circ}\right.$; Kostenidou et al., 2015), and and the low-volatility OOA (LV-OOA) spectra $\left(\theta=11^{\circ}\right)$ from both the DAURE (Mohr et al., 2012) and the SOAR campaign (Docherty et al., 2011). Higher theta angles $\left(\theta=20-40^{\circ}\right)$ were found when comparing the Patras OOA spectrum to spectra of SV-OOA (Fig. S31) from different studies, implying that the OOA in Patras was closer to LV-OOA, instead of SV-OOA.

The spectrum of OOA in Athens was similar to the M-OOA identified both in Athens $\left(\theta=8^{\circ}\right)$ and Patras $\left(\theta=10.6^{\circ}\right)$ during the summer (Kostenidou et al., 2015). It was also similar to the proposed biogenic OOA factor (bOOA; $\theta=10^{\circ}$ ) in Patras for the same summer period and to all the OOA (OOA-a, OOA-b, OOA-c) factors $\left(\theta=11-13^{\circ}\right)$ identified in the Po Valley (Saarikoski et al., 2012). The values of the theta angles between the OOA spectra in this study and spectra in the literature are summarized in Fig. S31.

\subsection{Hydrocarbon-like organic aerosol}

\subsubsection{Athens}

The HOA mean value was $0.95 \mu \mathrm{g} \mathrm{m}^{-3}$, and its hourly maximum concentration was $34 \mu \mathrm{g} \mathrm{m}^{-3}$. HOA was correlated with $\mathrm{CO}\left(R^{2}=0.69\right)$ and $\mathrm{NO}_{x}\left(R^{2}=0.74\right)$, suggesting that traffic was a major HOA source. HOA was also correlated with AMS chloride $\left(R^{2}=0.75\right)$ and VOCs, such as methacrolein (MACR; PTR-MS, $m / z 71 ; R^{2}=0.74$ ), naphthalene (PTR-MS, $m / z 129 ; R^{2}=0.73$ ), benzene (PTR-MS, $m / z 79 ; R^{2}=0.65$ ), and the xylenes (PTR-MS, $m / z 107$; $\left.R^{2}=0.7\right)$. The HOA correlation with $\mathrm{BC}$ for the whole campaign was low $\left(R^{2}=0.15\right)$. However, splitting the $\mathrm{BC}$ and HOA time series into two periods, one during the day (06:00-18:00 LST) and another one during the night (18:00-6:00 LST), led to high correlation during daytime $\left(R^{2}=0.78\right)$ and low correlation during nighttime $\left(R^{2}=0.15\right)$. A potential explanation of this behavior is that $\mathrm{BC}$ originated mainly from diesel combustion sources during the day, while during the night it was associated with both traffic and wood burning. The average diurnal pattern of HOA in Athens was the same as that of BC (Fig. S32), and it exhibited strong morning (08:00-09:00 LST) and evening peaks (20:00-23:00 LST) consistent with increased traffic during morning and evening rush hours.

\subsubsection{Patras}

HOA contributed on average approximately $10 \%$ to the total OA, while the corresponding HOA contribution during summer was $7 \%$ (Kostenidou et al., 2015). Its mean concentration was $2.1 \mu \mathrm{g} \mathrm{m}^{-3}$, and its hourly maximum value was $15.8 \mu \mathrm{g} \mathrm{m}^{-3}$. The strongest peak in the average diurnal cycle occurred in the morning (06:00-09:00 LST) and was probably associated with traffic emissions (Fig. 9). A peak in the afternoon (17:00-22:00 LST) was also present but was frequently smaller. The time series of HOA showed poor correlation with $\mathrm{NO}_{x}\left(R^{2}=0.16\right)$ and $\mathrm{BC}\left(R^{2}=0.2\right)$. Splitting again the $\mathrm{BC}$ and HOA time series into two periods, one during 04:00-16:00 LST and another one during 16:004:00 LST, led to a higher correlation during the first period $\left(R^{2}=0.48\right)$. However, no perfect correlation was expected, as the MAAP was monitoring $4 \mathrm{~km}$ away from the HR-ToFAMS.

In Athens, the $\mathrm{O}: \mathrm{C}$ for $\mathrm{HOA}$ was equal to 0.13 , while its $\mathrm{H}: \mathrm{C}$ ratio was 1.74 . In Patras, the $\mathrm{O}: \mathrm{C}$ ratio was 0.1 , while the $\mathrm{H}: \mathrm{C}$ ratio was equal to 1.83 . The corresponding values of $\mathrm{O}: \mathrm{C}$ during summertime of 2012 were 0.07 (Athens) and 0.1 (Patras; Kostenidou et al., 2015).

\subsubsection{HOA factor comparisons}

The two HOA spectra were also quite similar to each other $\left(\theta=13^{\circ}\right)$, having characteristic peaks at $m / z 41,43,55,57$, $69,71,83$, and 85 , with little signal at $m / z 44$ (Fig. S26). 
Their major differences were observed at $m / z 28,43,44,57$, 69 , and 71, which were generally higher on Patras. The $f_{44}$ in the Athens spectrum was 2 times higher (0.04) than the Patras one. These mass spectra of HOA are similar to those of diesel exhaust (Canagaratna et al., 2004; Schneider et al., 2005) and other incomplete combustion sources.

When comparing the identified HOA spectra with literature values, the spectrum of HOA in Athens was similar $\left(\theta=6^{\circ}\right)$ to the corresponding one from HOA in Patras during summertime (Kostenidou et al., 2015) and relatively similar to the majority of the other HOA spectra in the literature (Aiken et al., 2009; Crippa et al., 2013; Ge et al., 2012; Saarikoski et al., 2012; Sun et al., 2011; $\theta=10-15^{\circ}$ ), as presented in Fig. S33. The spectrum of HOA in Patras was very similar $\left(\theta=5-8^{\circ}\right)$ to the spectra of HOA in New York City (Sun et al., 2012), Fresno (Ge et al., 2012), and the MILAGRO campaign (Aiken et al., 2009).

\subsection{Cooking organic aerosol}

\subsubsection{Patras}

The COA factor identified during the campaign had a mean value of $2.1 \mu \mathrm{g} \mathrm{m}^{-3}$ and an hourly maximum value of $33.6 \mu \mathrm{g} \mathrm{m}^{-3}$. The diurnal profile of COA in Patras exhibited two peaks during the day. The major peak occurred in the late evening (18:00-24:00 LST), probably modulated by the boundary layer height, and a second significant peak around midday (10:00-15:00 LST), both corresponding to typical Greek mealtimes (Fig. 9). Its contribution was similar to that of HOA.

\subsubsection{Athens}

In Athens, COA exhibited strong night peaks at around 23:00 LST, with values up to $15 \mu \mathrm{g} \mathrm{m}^{-3}$. Its mean value was $0.9 \mu \mathrm{g} \mathrm{m}^{-3}$. COA correlated moderately with $\mathrm{BC}$ $\left(R^{2}=0.32\right)$ and $\mathrm{CO}\left(R^{2}=0.27\right)$, while the correlation between COA and individual VOCs measured by the PTR-MS was relatively poor, with $R^{2}$ varying from 0.01 to 0.32 . The temporal trend of COA in Athens is different from those in previous studies. Contrary to what was expected, no peak was found during lunch hours (12:00-15:00 LST). However, no other factor displayed a peak during these hours because of the meteorology (strong winds). A large nighttime peak, clearly affected by the decrease of the planetary boundary layer, was present at around 23:00 LST (Fig. 9). This late peak is consistent with the late dinner hours of Athenians.

In Patras, the COA O : $\mathrm{C}$ ratio was 0.14 , while the $\mathrm{H}: \mathrm{C}$ ratio was equal to 1.71 . In Athens, the $\mathrm{O}: \mathrm{C}$ was 0.11 , while the $\mathrm{H}: \mathrm{C}$ was equal to 1.68 . The corresponding values of $\mathrm{COA}$ $\mathrm{O}: \mathrm{C}$ during summertime of 2012 were 0.21 (Athens) and 0.24 (Patras; Kostenidou et al., 2015).

\subsubsection{COA factor comparisons}

The COA spectrum, like the HOA one, was characterized by the ion series $\mathrm{C}_{n} \mathrm{H}_{2 n-1}^{+}$, as well as by $\mathrm{C}_{m} \mathrm{H}_{2 m-1} \mathrm{CO}^{+}$ $(m / z 41,55,69,83$, etc. $)$ and $\mathrm{C}_{m} \mathrm{H}_{2 m+1} \mathrm{CO}^{+}(m / z, 29,43,57$, 71, 85, etc.; Crippa et al., 2013; He et al., 2010; Fig. 8a). The COA spectra in both cities shared some similarities with the HOA spectra but were dominated by $m / z 41$ and 55 instead of $m / z 43$ and 57. The signal of $m / z 55$ in the COA spectrum in Patras was almost twice that of $m / z 57$. This characteristic of the COA spectrum was first reported by Lanz et al. (2007) and is related to charbroiling (Allan et al., 2010). The COA mass spectra in the two cities were very similar to each other, with a theta angle of $8^{\circ}$, and had only minor differences at $m / z$ 27, 28, 39, 41, and 43 (Fig. S26). The COA spectrum in Athens and Patras was rather similar to the COA spectra reported in Fresno (Ge et al., 2012), New York City (Sun et al., 2012), and Paris (Crippa et al., 2013), with theta angle values varying between 11 and $17^{\circ}$ (Fig. S34). When comparing the identified COA spectra with the corresponding ones (called HOA-2) in Athens and Patras during summertime (Kostenidou et al., 2015), theta values higher than $20^{\circ}$ were observed.

The location of COA and the other factors in the $m / z 43$ fraction versus $m / z 44$ fraction $\left(f_{43}\right.$ and $\left.f_{44}\right)$ plot suggested by $\mathrm{Ng}$ et al. (2009) is shown in Figs. S35 and S36.

\section{Conclusions}

An aerosol mass spectrometer (HR-ToF-AMS) accompanied by a suite of aerosol- and gas-related instruments was used for the characterization of the OA in two of the biggest cities of Greece (Athens and Patras), during two consecutive winter periods (2012 and 2013). The carbonaceous PM (BC+OA) accounted for about $80 \%$ of the measured $\mathrm{PM}_{1}$ during the two field campaigns and up to $95 \%$ during morning (05:0010:00 LST) and evening (16:00-24:00 LST) hours.

During both wintertime campaigns, domestic wood burning was in general a more significant OA source than traffic. The $\mathrm{PM}_{1}$ consisted of biomass-burning-related $\mathrm{OA}$ $(25-42 \%)$, a contribution from traffic $(\mathrm{BC}=7-20 \%$ and $\mathrm{HOA}=9-10 \%)$, cooking activities $(\mathrm{COA}=8-9 \%)$, and also oxygenated $\mathrm{OA}(\mathrm{OOA}=13-15 \%)$. Sulfates, ammonium, and nitrate accounted for 10,4 , and $5 \%$, respectively, of the total $\mathrm{PM}_{1}$ in both cities. The $\mathrm{OA} \mathrm{O}: \mathrm{C}$ ratio for the Athens campaign was equal to 0.32, while in Patras it was 0.42 , suggesting that the atmosphere in Athens had higher contributions on average by less processed emissions.

Biomass-burning-related factors were the dominant source (40-60\%) of OA in both cities, and their mass concentration levels increased sharply during the evening hours (18:00 24:00 LST). The BBOA-I in Patras reached its maximum value at 20:00 LST, $3 \mathrm{~h}$ earlier than the BBOA factor in Athens. A second biomass-burning-related factor (BBOA-II) 
was also identified in Patras. The BBOA-II (19\% of OA) had a quite different mass spectrum than the dominant BBOA-I factor. The two BBOA factors (BBOA-I and BBOA-II) exhibited different diurnal profiles but comparable $\mathrm{O}: \mathrm{C}$ ratios (0.30 and 0.26). In Athens, only one BBOA factor was identified by the PMF analysis.

At both sites the HOA factor had two peaks: one during morning (08:00-09:00 LST) and one during evening (20:0023:00 LST) hours. Its diurnal pattern in Athens followed closely that of $\mathrm{BC}$, exhibiting strong peaks consistent with increased traffic during morning and evening rush hours. The two HOA spectra were quite similar to each other $\left(\theta=13^{\circ}\right)$ and to the corresponding spectra reported in campaigns in New York City, Fresno, and Mexico City.

The diurnal profile of COA in Athens exhibited strong peaks only during the night at around 23:00 LST, while COA in Patras exhibited two major peaks during the day (13:00 and 22:00 LST). The two COA mass spectra were very similar to each other, with a theta angle of $8^{\circ}$, and also quite similar to COA spectra in Fresno, New York City, and Paris.

The OOA factor dominated daytime OA at both sites and correlated reasonably well with inorganic compounds. In comparison to summertime campaigns in the same cities during 2012, only one type of OOA was present during wintertime. The spectra of OOA in the two cities were quite similar $\left(\theta=11^{\circ}\right)$ to each other and were quite comparable $(\theta=8$ $\left.11^{\circ}\right)$ to the more oxygenated OA (M-OOA) identified during the summertime study.

Both measurement campaigns were conducted during relatively warm wintertime periods. The average ambient temperature for both campaigns was close to $12^{\circ} \mathrm{C}$, ranging 6$19^{\circ} \mathrm{C}$ in Athens and $4-16^{\circ} \mathrm{C}$ in Patras. The contribution of wood burning is expected to be even higher for lower temperatures.

\section{Data availability}

The AMS and other measurements in Patras and Athens as well as the results of the corresponding PMF analysis during the two campaigns are available on request from Spyros Pandis (spyros@chemeng.upatras.gr).

\section{The Supplement related to this article is available online at doi:10.5194/acp-17-3145-2017-supplement.}

Competing interests. The authors declare that they have no conflict of interest.

Acknowledgements. The authors would like to acknowledge E. Kostenidou for her guidance and advice, and also A. Papalou from the Technological Educational Institute (TEI) of Patras and E. Gerasopoulos from the Institute of Environmental Research and
Sustainable Development (IERSD) of the National Observatory of Athens (NOA), for providing the space during the Patras and Athens measurements, respectively. This research was supported by the European Research Council Project ATMOPACS (Atmospheric Organic Particulate Matter, Air Quality and Climate Change Studies; grant agreement 267099), the European Social Fund (ESF) and Greek national funds through the National Strategic Reference Framework (NSRF) programs Aristeia and Thales: "Identify sources and physicochemical properties of fine and ultrafine suspended aerosol particles that affect the regional climate of Greece".

Edited by: S. Brown

Reviewed by: two anonymous referees

\section{References}

Aiken, A. C., Decarlo, P. F., Kroll, J. H., Worsnop, D. R., Huffman, J. A., Docherty, K. S., Ulbrich, I. M., Mohr, C., Kimmel, J. R., Sueper, D., Sun, Y., Zhang, Q., Trimborn, A., Northway, M., Ziemann, P. J., Canagaratna, M. R., Onasch, T. B., Alfarra, M. R., Prévôt, A. S. H., Dommen, J., Duplissy, J., Metzger, A., Baltensperger, U., and Jimenez, J. L.: O / C and OM / OC ratios of primary, secondary, and ambient organic aerosols with high-resolution time-of-flight aerosol mass spectrometry, Environ. Sci. Technol., 42, 4478-4485, 2008.

Aiken, A. C., Salcedo, D., Cubison, M. J., Huffman, J. A., DeCarlo, P. F., Ulbrich, I. M., Docherty, K. S., Sueper, D., Kimmel, J. R., Worsnop, D. R., Trimborn, A., Northway, M., Stone, E. A., Schauer, J. J., Volkamer, R. M., Fortner, E., de Foy, B., Wang, J., Laskin, A., Shutthanandan, V., Zheng, J., Zhang, R., Gaffney, J., Marley, N. A., Paredes-Miranda, G., Arnott, W. P., Molina, L. T., Sosa, G., and Jimenez, J. L.: Mexico City aerosol analysis during MILAGRO using high resolution aerosol mass spectrometry at the urban supersite (T0) - Part 1: Fine particle composition and organic source apportionment, Atmos. Chem. Phys., 9, 6633-6653, doi:10.5194/acp-9-6633-2009, 2009.

Akagi, S. K., Yokelson, R. J., Wiedinmyer, C., Alvarado, M. J., Reid, J. S., Karl, T., Crounse, J. D., and Wennberg, P. O.: Emission factors for open and domestic biomass burning for use in atmospheric models, Atmos. Chem. Phys., 11, 4039-4072, doi:10.5194/acp-11-4039-2011, 2011.

Alfarra, M. R., Coe, H., Allan, J. D., Bower, K. N., Boudries, H., Canagaratna, M. R., Jimenez, J. L., Jayne, J. T., Garforth, A. A., Li, S.-M., and Worsnop, D. R.: Characterization of urban and rural organic particulate in the Lower Fraser Valley using two Aerodyne Aerosol Mass Spectrometers, Atmos. Environ., 38, 5745-5758, doi:10.1016/j.atmosenv.2004.01.054, 2004.

Alfarra, M. R., Paulsen, D., Gysel, M., Garforth, A. A., Dommen, J., Prévôt, A. S. H., Worsnop, D. R., Baltensperger, U., and Coe, H.: A mass spectrometric study of secondary organic aerosols formed from the photooxidation of anthropogenic and biogenic precursors in a reaction chamber, Atmos. Chem. Phys., 6, 52795293, doi:10.5194/acp-6-5279-2006, 2006.

Alfarra, M. R., Prévôt, A. S. H., Szidat, S., Sandradewi, J., Weimer, S., Lanz, V. A., Schreiber, D., Mohr, M., and Baltensperger, U.: Identification of the mass spectral signature of organic aerosols 
from wood burning emissions, Environ. Sci. Technol., 41, 5770_ 5777, 2007.

Allan, J. D., Jimenez, J. L., Williams, P. I., Alfarra, M. R., Bower, K. N., Jayne, J. T., Coe, H., and Worsnop, D. R.: Quantitative sampling using an Aerodyne aerosol mass spectrometer 1. Techniques of data interpretation and error analysis, J. Geophys. Res., 108, 4090, doi:10.1029/2002JD002358, 2003.

Allan, J. D., Delia, A. E., Coe, H., Bower, K. N., Alfarra, M. R., Jimenez, J. L., Middlebrook, A. M., Drewnick, F., Onasch, T. B., Canagaratna, M. R., Jayne, J. T., and Worsnop, D. R.: A generalised method for the extraction of chemically resolved mass spectra from Aerodyne aerosol mass spectrometer data, J. Aerosol Sci., 35, 909-922, doi:10.1016/j.jaerosci.2004.02.007, 2004.

Allan, J. D., Williams, P. I., Morgan, W. T., Martin, C. L., Flynn, M. J., Lee, J., Nemitz, E., Phillips, G. J., Gallagher, M. W., and Coe, H.: Contributions from transport, solid fuel burning and cooking to primary organic aerosols in two UK cities, Atmos. Chem. Phys., 10, 647-668, doi:10.5194/acp-10-647-2010, 2010.

An, W. J., Pathak, R. K., Lee, B.-H., and Pandis, S. N.: Aerosol volatility measurement using an improved thermodenuder: Application to secondary organic aerosol, J. Aerosol Sci., 38, 305314, doi:10.1016/j.jaerosci.2006.12.002, 2007.

Argyropoulos, G., Manoli, E., Kouras, A., and Samara, C.: Concentrations and source apportionment of $\mathrm{PM}_{10}$ and associated major and trace elements in the Rhodes Island, Greece, Sci. Total Environ., 432, 12-22, doi:10.1016/j.scitotenv.2012.05.076, 2012.

Bond, T. C, Streets, D. G., Yarber, K. F., Nelson, S. M., Woo, J.-H., and Klimont, Z: A technology-based global inventory of black and organic carbon emissions from combustion, J. Geophys. Res., 109, D14203, doi:10.1029/2003JD003697, 2004.

Borbon, A., Fontaine, H., Veillerot, M., Locoge, N., Galloo, J. C., and Guillermo, R.: An investigation into the traffic-related fraction of isoprene at an urban location, Atmos. Environ., 35, 37493760, doi:10.1016/S1352-2310(01)00170-4, 2001.

Burling, I. R., Yokelson, R. J., Griffith, D. W. T., Johnson, T. J., Veres, P., Roberts, J. M., Warneke, C., Urbanski, S. P., Reardon, J., Weise, D. R., Hao, W. M., and de Gouw, J.: Laboratory measurements of trace gas emissions from biomass burning of fuel types from the southeastern and southwestern United States, Atmos. Chem. Phys., 10, 11115-11130, doi:10.5194/acp10-11115-2010, 2010.

Canagaratna, M. R., Jayne, J. T., Ghertner, D. A., Herndon, S., Shi, Q., Jimenez, J. L., Silva, P. J., Williams, P., Lanni, T., Drewnick, F., Demerjian, K. L., Kolb, C. E., and Worsnop, D. R.: Chase studies of particulate emissions from in-use New York City vehicles, Aerosol Sci. Technol., 38, 555-573, doi:10.1080/02786820490465504, 2004.

Canagaratna, M. R., Jayne, J. T., Jimenez, J. L., Allan, J. D., Alfarra, M. R., Zhang, Q., Onasch, T. B., Drewnick, F., Coe, H., Middlebrook, A., Delia, A., Williams, L. R., Trimborn, A. M., Northway, M. J., DeCarlo, P. F., Kolb, C. E., Davidovits, P., and Worsnop, D. R.: Chemical and microphysical characterization of ambient aerosols with the aerodyne aerosol mass spectrometer, Mass Spectrom. Rev., 26, 185-222, doi:10.1002/mas.20115, 2007.

Canagaratna, M. R., Jimenez, J. L., Kroll, J. H., Chen, Q., Kessler, S. H., Massoli, P., Hildebrandt Ruiz, L., Fortner, E., Williams, L. R., Wilson, K. R., Surratt, J. D., Donahue, N. M., Jayne, J. T., and Worsnop, D. R.: Elemental ratio measurements of organic compounds using aerosol mass spectrometry: characterization, improved calibration, and implications, Atmos. Chem. Phys., 15, 253-272, doi:10.5194/acp-15-253-2015, 2015.

Chaloulakou, A., Kassomenos, P., Spyrellis, N., Demokritou, P., and Koutrakis, P.: Measurements of $\mathrm{PM}_{10}$ and $\mathrm{PM}_{2.5}$ particle concentrations in Athens, Greece, Atmos. Environ., 37, 649-660, doi:10.1016/S1352-2310(02)00898-1, 2003.

Coggon, M.M., Veres, P.R., Yuan, B., Koss, A., Warneke, C., Gilman, J.B., Lerner, B., Peischl, J., Aikin, K., Stockwell, C., Hatch, L., Ryerson, T.B., Roberts, J.M., Yokelson, R., and de Gouw, J. A.: Emissions of nitrogen-containing organic compounds from the burning of herbaceous and arboraceous biomass: Fuel composition dependence and the variability of commonly used nitrile tracers, Geophys. Res. Lett., 43, 99039912, doi:10.1002/2016GL070562, 2016.

Cottrell, L. D., Griffin, R. J., Jimenez, J. L., Zhang, Q., Ulbrich, I., Ziemba, L. D., Beckman, P. J., Sive, B. C., and Talbot, R. W.: Submicron particles at Thompson Farm during ICARTT measured using aerosol mass spectrometry, J. Geophys. Res., 113, D08212, doi:10.1029/2007JD009192, 2008.

Crippa, M., DeCarlo, P. F., Slowik, J. G., Mohr, C., Heringa, M. F., Chirico, R., Poulain, L., Freutel, F., Sciare, J., Cozic, J., Di Marco, C. F., Elsasser, M., Nicolas, J. B., Marchand, N., Abidi, E., Wiedensohler, A., Drewnick, F., Schneider, J., Borrmann, S., Nemitz, E., Zimmermann, R., Jaffrezo, J.-L., Prévôt, A. S. H., and Baltensperger, U.: Wintertime aerosol chemical composition and source apportionment of the organic fraction in the metropolitan area of Paris, Atmos. Chem. Phys., 13, 961-981, doi:10.5194/acp-13-961-2013, 2013.

Cubison, M. J., Ortega, A. M., Hayes, P. L., Farmer, D. K., Day, D., Lechner, M. J., Brune, W. H., Apel, E., Diskin, G. S., Fisher, J. A., Fuelberg, H. E., Hecobian, A., Knapp, D. J., Mikoviny, T., Riemer, D., Sachse, G. W., Sessions, W., Weber, R. J., Weinheimer, A. J., Wisthaler, A., and Jimenez, J. L.: Effects of aging on organic aerosol from open biomass burning smoke in aircraft and laboratory studies, Atmos. Chem. Phys., 11, 12049-12064, doi:10.5194/acp-11-12049-2011, 2011.

Dall'Osto, M. and Harrison, R.: Chemical characterisation of single airborne particles in Athens (Greece) by ATOFMS, Atmos. Environ., 40, 7614-7631, doi:10.1016/j.atmosenv.2006.06.053, 2006.

DeCarlo, P. F., Kimmel, J. R., Trimborn, A., Northway, M. J., Jayne, J. T., Aiken, A. C., Gonin, M., Fuhrer, K., Horvath, T., Docherty, K. S., Worsnop, D. R., and Jimenez, J. L.: Field-deployable, high-resolution, time-of-flight aerosol mass spectrometer, Anal. Chem., 78, 8281-8299, doi:10.1021/ac061249n, 2006.

Docherty, K. S., Aiken, A. C., Huffman, J. A., Ulbrich, I. M., DeCarlo, P. F., Sueper, D., Worsnop, D. R., Snyder, D. C., Peltier, R. E., Weber, R. J., Grover, B. D., Eatough, D. J., Williams, B. J., Goldstein, A. H., Ziemann, P. J., and Jimenez, J. L.: The 2005 Study of Organic Aerosols at Riverside (SOAR-1): instrumental intercomparisons and fine particle composition, Atmos. Chem. Phys., 11, 12387-12420, doi:10.5194/acp-11-12387-2011, 2011.

Drewnick, F., Hings, S. S., DeCarlo, P., Jayne, J. T., Gonin, M., Fuhrer, K., Weimer, S., Jimenez, J. L., Demerjian, K. L., Borrmann, S., and Worsnop, D. R.: A new Time-of-Flight Aerosol Mass Spectrometer (TOF-AMS) - Instrument description and first field deployment, Aerosol Sci. Technol., 39, 637-658, doi:10.1080/02786820500182040, 2005. 
Farmer, D. K., Matsunaga, A., Docherty, K. S., Surratt, J. D., Seinfeld, J. H., Ziemann P. J., and Jimenez, J. L.: Response of an aerosol mass spectrometer to organonitrates and organosulfates and implications for atmospheric chemistry, P. Natl. Acad. Sci. USA, 107, 6670-6675, doi:10.1073/pnas.0912340107, 2010.

Favez, O., El Haddad, I., Piot, C., Boréave, A., Abidi, E., Marchand, N., Jaffrezo, J.-L., Besombes, J.-L., Personnaz, M.-B., Sciare, J., Wortham, H., George, C., and D'Anna, B.: Inter-comparison of source apportionment models for the estimation of wood burning aerosols during wintertime in an Alpine city (Grenoble, France), Atmos. Chem. Phys., 10, 5295-5314, doi:10.5194/acp-10-52952010, 2010.

Fry, J. L., Kiendler-Scharr, A., Rollins, A. W., Wooldridge, P. J., Brown, S. S., Fuchs, H., Dubé, W., Mensah, A., dal Maso, M., Tillmann, R., Dorn, H.-P., Brauers, T., and Cohen, R. C.: Organic nitrate and secondary organic aerosol yield from $\mathrm{NO}_{3}$ oxidation of $\beta$-pinene evaluated using a gas-phase kinetics/aerosol partitioning model, Atmos. Chem. Phys., 9, 14311449, doi:10.5194/acp-9-1431-2009, 2009.

Fuller, G. W., Sciare, J., Lutz, M., Moukhtar, S., and Wagener, S.: New Directions: Time to tackle urban wood burning?, Atmos. Environ., 68, 295-296, doi:10.1016/j.atmosenv.2012.11.045, 2013.

Fuller, G. W., Tremper, A. H., Baker, T. D., Yttri, K. E., and Butterfield, D.: Contribution of wood burning to $\mathrm{PM}_{10}$ in London, Atmos. Environ., 87, 87-94, doi:10.1016/j.atmosenv.2013.12.037, 2014.

Gaidajis, G., Angelakoglou, K., and Aktsoglou, D.: Wintertime particulate mass concentrations in urban environment and the impact of economic crisis, J. Environ. Sci. Heal. A, 49, 1653-60, doi:10.1080/10934529.2014.951221, 2014.

Ge, X., Setyan, A., Sun, Y., and Zhang, Q.: Primary and secondary organic aerosols in Fresno, California during wintertime: Results from high resolution aerosol mass spectrometry, J. Geophys. Res., 117, D19301, doi:10.1029/2012JD018026, 2012.

Gilman, J. B., Lerner, B. M., Kuster, W. C., Goldan, P. D., Warneke, C., Veres, P. R., Roberts, J. M., de Gouw, J. A., Burling, I. R., and Yokelson, R. J.: Biomass burning emissions and potential air quality impacts of volatile organic compounds and other trace gases from fuels common in the US, Atmos. Chem. Phys., 15, 13915-13938, doi:10.5194/acp-15-13915-2015, 2015.

Gkatzelis, G. I., Papanastasiou, D. K., Florou, K., Kaltsonoudis, C., Louvaris, E., and Pandis, S. N.: Measurement of nonvolatile particle number size distribution, Atmos. Meas. Tech., 9, 103-114, doi:10.5194/amt-9-103-2016, 2016.

Grantz, D. A., Garner, J. H. B., and Johnson, D. W.: Ecological effects of particulate matter, Environ. Int., 29, 213-39, doi:10.1016/S0160-4120(02)00181-2, 2003.

Hallquist, M., Wenger, J. C., Baltensperger, U., Rudich, Y., Simpson, D., Claeys, M., Dommen, J., Donahue, N. M., George, C., Goldstein, A. H., Hamilton, J. F., Herrmann, H., Hoffmann, T., Iinuma, Y., Jang, M., Jenkin, M. E., Jimenez, J. L., Kiendler-Scharr, A., Maenhaut, W., McFiggans, G., Mentel, Th. F., Monod, A., Prévôt, A. S. H., Seinfeld, J. H., Surratt, J. D., Szmigielski, R., and Wildt, J.: The formation, properties and impact of secondary organic aerosol: current and emerging issues, Atmos. Chem. Phys., 9, 5155-5236, doi:10.5194/acp-9-51552009, 2009.
Hao, L. Q., Kortelainen, A., Romakkaniemi, S., Portin, H., Jaatinen, A., Leskinen, A., Komppula, M., Miettinen, P., Sueper, D., Pajunoja, A., Smith, J. N., Lehtinen, K. E. J., Worsnop, D. R., Laaksonen, A., and Virtanen, A.: Atmospheric submicron aerosol composition and particulate organic nitrate formation in a boreal forestland-urban mixed region, Atmos. Chem. Phys., 14, 1348313495, doi:10.5194/acp-14-13483-2014, 2014.

Hatch, L. E., Luo, W., Pankow, J. F., Yokelson, R. J., Stockwell, C. E., and Barsanti, K. C.: Identification and quantification of gaseous organic compounds emitted from biomass burning using two-dimensional gas chromatography-time-of-flight mass spectrometry, Atmos. Chem. Phys., 15, 1865-1899, doi:10.5194/acp15-1865-2015, 2015.

He, L.-Y., Lin, Y., Huang, X.-F., Guo, S., Xue, L., Su, Q., Hu, M., Luan, S.-J., and Zhang, Y.-H.: Characterization of highresolution a erosol mass spectra of primary organic aerosol emissions from Chinese cooking and biomass burning, Atmos. Chem. Phys., 10, 11535-11543, doi:10.5194/acp-10-11535-2010, 2010.

Heringa, M. F., DeCarlo, P. F., Chirico, R., Tritscher, T., Dommen, J., Weingartner, E., Richter, R., Wehrle, G., Prévôt, A. S. H., and Baltensperger, U.: Investigations of primary and secondary particulate matter of different wood combustion appliances with a high-resolution time-of-flight aerosol mass spectrometer, Atmos. Chem. Phys., 11, 5945-5957, doi:10.5194/acp-11-59452011, 2011.

Herndon, S. C., Onasch, T. B., Wood, E. C., Kroll, J. H., Canagaratna, M. R., Jayne, J. T., Zavala, M. A., Knighton, W. B., Mazzoleni, C., Dubey, M. K., Ulbrich, I. M., Jimenez, J. L., Seila, R., de Gouw, J. A., de Foy, B., Fast, J., Molina, L. T., Kolb, C. E., and Worsnop, D. R.: Correlation of secondary organic aerosol with odd oxygen in Mexico City, Geophys. Res. Lett., 35, L15804, doi:10.1029/2008GL034058, 2008.

Hodzic, A., Jimenez, J. L., Madronich, S., Aiken, A. C., Bessagnet, B., Curci, G., Fast, J., Lamarque, J.-F., Onasch, T. B., Roux, G., Schauer, J. J., Stone, E. A., and Ulbrich, I. M.: Modeling organic aerosols during MILAGRO: importance of biogenic secondary organic aerosols, Atmos. Chem. Phys., 9, 6949-6981, doi:10.5194/acp-9-6949-2009, 2009.

Huang, M., Carmichael, G. R., Spak, S. N., Adhikary, B., Kulkarni, S., Cheng, Y., Wei, C., Tang, Y., D’Allura, A., Wennberg, P. O., Huey, G. L., Dibb, J. E., Jimenez, J. L., Cubison, M. J., Weinheimer, A. J., Kaduwela, A., Cai, C., Wong, M., Bradley Pierce, R., Al-Saadi, J. A., Streets, D. G., and Zhang, Q.: Multi-scale modeling study of the source contributions to nearsurface ozone and sulfur oxides levels over California during the ARCTAS-CARB period, Atmos. Chem. Phys., 11, 3173-3194, doi:10.5194/acp-11-3173-2011, 2011.

Jayne, J. T., Leard, D. C., Zhang, X., Davidovits, P., Smith, K. A., Kolb, C. E., and Worsnop, D. R.: Development of an Aerosol Mass Spectrometer for size and composition analysis of submicron particles, Aerosol Sci. Technol., 33, 49-70, doi:10.1080/027868200410840, 2000.

Jimenez, J. L., Canagaratna, M. R., Donahue, N. M., Prévôt, A. S. H., Zhang, Q., Kroll, J. H., DeCarlo, P. F., Allan, J. D., Coe, H., Ng, N. L., Aiken, A C., Docherty, K. S., Ulbrich, I. M., Grieshop, A. P., Robinson, A. L., Duplissy, J., Smith, J. D., Wilson, K. R., Lanz, V. A., Hueglin, C., Sun, Y. L., Tian, J., Laaksonen, A, Raatikainen, T., Rautiainen, J., Vaattovaara, P., Ehn, M., Kulmala, M., Tomlinson, J. M., Collins, D. R., Cubison, M. J., Dun- 
lea, E. J., Huffman, J. A., Onasch, T. B., Alfarra, M. R., Williams, P. I., Bower, K., Kondo, Y., Schneider, J., Drewnick, F., Borrmann, S., Weimer, S., Demerjian, K., Salcedo, D., Cottrell, L., Griffin, R., Takami, A., Miyoshi, T., Hatakeyama, S., Shimono, A., Sun, J. Y., Zhang, Y. M., Dzepina, K., Kimmel, J. R., Sueper, D., Jayne, J. T., Herndon, S. C., Trimborn, A. M., Williams, L. R., Wood, E. C., Middlebrook, A. M., Kolb, C. E., Baltensperger, U., and Worsnop, D. R.: Evolution of organic aerosols in the atmosphere, Science, 326, 1525-1529, doi:10.1126/science.1180353, 2009.

Kaltsonoudis, C., Kostenidou, E., Florou, K., Psichoudaki, M., and Pandis, S. N.: Temporal variability and sources of VOCs in urban areas of the eastern Mediterranean, Atmos. Chem. Phys., 16, 14825-14842, doi:10.5194/acp-16-14825-2016, 2016.

Kanakidou, M., Seinfeld, J. H., Pandis, S. N., Barnes, I., Dentener, F. J., Facchini, M. C., Van Dingenen, R., Ervens, B., Nenes, A., Nielsen, C. J., Swietlicki, E., Putaud, J. P., Balkanski, Y., Fuzzi, S., Horth, J., Moortgat, G. K., W interhalter, R., Myhre, C. E. L., Tsigaridis, K., Vignati, E., Stephanou, E. G., and Wilson, J.: Organic aerosol and global climate modelling: a review, Atmos. Chem. Phys., 5, 1053-1123, doi:10.5194/acp-5-1053-2005, 2005.

Katragkou, E., Kazadzis, S., Amiridis, V., Papaioannou, V., Karathanasis, S., and Melas, D.: $\mathrm{PM}_{10}$ regional transport pathways in Thessaloniki, Greece, Atmos. Environ., 43, 1079-1085, doi:10.1016/j.atmosenv.2008.11.021, 2009.

Kostenidou, E., Pathak, R. K., and Pandis, S. N.: An algorithm for the calculation of secondary organic aerosol density combining AMS and SMPS Data, Aerosol Sci. Technol., 41, 1002-1010, doi:10.1080/02786820701666270, 2007.

Kostenidou, E., Lee, B.-H., Engelhart, G. J., Pierce, J. R., and Pandis, S. N.: Mass spectra deconvolution of low, medium, and high volatility biogenic secondary organic aerosol, Environ. Sci. Technol., 43, 4884-4889, 2009.

Kostenidou, E., Kaltsonoudis, C., Tsiflikiotou, M., Louvaris, E., Russell, L. M., and Pandis, S. N.: Burning of olive tree branches: a major organic aerosol source in the Mediterranean, Atmos. Chem. Phys., 13, 8797-8811, doi:10.5194/acp-13-8797-2013, 2013.

Kostenidou, E., Florou, K., Kaltsonoudis, C., Tsiflikiotou, M., Vratolis, S., Eleftheriadis, K., and Pandis, S. N.: Sources and chemical characterization of organic aerosol during the summer in the eastern Mediterranean, Atmos. Chem. Phys., 15, 11355-11371, doi:10.5194/acp-15-11355-2015, 2015.

Koulouri, E., Saarikoski, S., Theodosi, C., Markaki, Z., Gerasopoulos, E., Kouvarakis, G., Makela, T., Hillamo, R., and Mihalopoulos, N.: Chemical composition and sources of fine and coarse aerosol particles in the Eastern Mediterranean, Atmos. Environ., 42, 6542-6550, doi:10.1016/j.atmosenv.2008.04.010, 2008.

Kroll, J. H., Donahue, N. M., Jimenez, J. L., Kessler, S. H., Canagaratna, M. R., Wilson, K. R., Altieri, K. E., Mazzoleni, L. R., Wozniak, A. S., Bluhm, H., Mysak, E. R., Smith, J. D., Kolb, C. E., and Worsnop, D. R.: Carbon oxidation state as a metric for describing the chemistry of atmospheric organic aerosol, Nat. Chem., 3, 133-139, doi:10.1038/nchem.948, 2011.

Langford, B., Davison, B., Nemitz, E., and Hewitt, C. N.: Mixing ratios and eddy covariance flux measurements of volatile organic compounds from an urban canopy (Manchester, UK), At- mos. Chem. Phys., 9, 1971-1987, doi:10.5194/acp-9-1971-2009, 2009.

Lanz, V. A., Alfarra, M. R., Baltensperger, U., Buchmann, B., Hueglin, C., and Prévôt, A. S. H.: Source apportionment of submicron organic aerosols at an urban site by factor analytical modelling of aerosol mass spectra, Atmos. Chem. Phys., 7, 15031522, doi:10.5194/acp-7-1503-2007, 2007.

Lanz, V. A, Alfarra, M. R., Baltensperger, U., Buchmann, B., Hueglin, C., Szidat, S., Wehrli, M. N., Wacker, L., Weimer, S., Caseiro, A., Puxbaum, H., and Prévôt, A. S. H.: Source attribution of submicron organic aerosols during wintertime inversions by advanced factor analysis of aerosol mass spectra, Environ. Sci. Technol., 42, 214-220, 2008.

Lelieveld, J., Crutzen, P. J., Ramanathan, V., Andreae, M. O., Brenninkmeijer, C. M., Campos, T., Cass, G. R., Dickerson, R. R., Fischer, H., de Gouw, J. A., Hansel, A., Jefferson, A., Kley, D., de Laat, A. T., Lal, S., Lawrence, M. G., Lobert, J. M., MayolBracero, O. L., Mitra, A. P., Novakov, T., Oltmans, S. J., Prather, K. A., Reiner, T., Rodhe, H., Scheeren, H. A., Sikka, D., and Williams, J.: The Indian Ocean experiment: widespread air pollution from South and Southeast Asia, Science, 291, 1031-1036, doi:10.1126/science.1057103, 2001.

Louvaris, E., Florou, K., Karnezi, E., Gkatzelis, G., Papanastasiou, D., and Pandis, S. N.: Volatility of source apportioned wintertime organic aerosol in the city of Athens, ATMENV-D-16-01625, Atmos. Environ., submitted, 2017.

Mohr, C., Huffman, J. A., Cubison, M. J., Aiken, A. C., Docherty, K. S., Kimmel, J. R., Ulbrich, I. M., Hannigan, M., and Jimenez, J. L.: Characterization of primary organic aerosol emissions from meat cooking, trash burning, and motor vehicles with HighResolution Aerosol Mass Spectrometry and comparison with ambient and chamber observations, Environ. Sci. Technol., 43, 2443-2449, doi:10.1021/es8011518, 2009.

Mohr, C., DeCarlo, P. F., Heringa, M. F., Chirico, R., Slowik, J. G., Richter, R., Reche, C., Alastuey, A., Querol, X., Seco, R., Peñuelas, J., Jiménez, J. L., Crippa, M., Zimmermann, R., Baltensperger, U., and Prévôt, A. S. H.: Identification and quantification of organic aerosol from cooking and other sources in Barcelona using aerosol mass spectrometer data, Atmos. Chem. Phys., 12, 1649-1665, doi:10.5194/acp-12-1649-2012, 2012.

Murphy, B. N., Donahue, N. M., Fountoukis, C., and Pandis, S. N.: Simulating the oxygen content of ambient organic aerosol with the 2D volatility basis set, Atmos. Chem. Phys., 11, 7859-7873, doi:10.5194/acp-11-7859-2011, 2011.

Nel, A.: Atmosphere, Air pollution-related illness: effects of particles, Science, 308, 804-806, doi:10.1126/science.1108752, 2005.

Ng, N. L., Kwan, A. J., Surratt, J. D., Chan, A. W. H., Chhabra, P. S., Sorooshian, A., Pye, H. O. T., Crounse, J. D., Wennberg, P. O., Flagan, R. C., and Seinfeld, J. H.: Secondary organic aerosol (SOA) formation from reaction of isoprene with nitrate radicals $\left(\mathrm{NO}_{3}\right)$, Atmos. Chem. Phys., 8, 4117-4140, doi:10.5194/acp-84117-2008, 2008.

Paatero, P. and Tapper, U.: Positive matrix factorization: A non-negative factor model with optimal utilization of error estimates of data values, Environmetrics, 5, 111-126, doi:10.1002/env.3170050203, 1994.

Paraskevopoulou, D., Liakakou, E., Gerasopoulos, E., Theodosi, C., and Mihalopoulos, N.: Long-term characterization of or- 
ganic and elemental carbon in the $\mathrm{PM}_{2.5}$ fraction: the case of Athens, Greece, Atmos. Chem. Phys., 14, 13313-13325, doi:10.5194/acp-14-13313-2014, 2014.

Petrakakis, M. J., Kelessis, A. G., Tzoumaka, P., and Samara, C.: Levels of Suspended Particulate Matter before and after the Economic Crisis in Thessaloniki, Greece, Proceedings of 17th International Symposium on Environmental Pollution and its Impact on Life in the Mediterranean Region, Istanbul, Turkey, 28 September-1 October, Mediterranean Scientific Association of Environmental Protection (MESAEP), 2013.

Petzold, A. and Schönlinner, M.: Multi-angle absorption photometry - a new method for the measurement of aerosol light absorption and atmospheric black carbon, J. Aerosol Sci., 35, 421-441, doi:10.1016/j.jaerosci.2003.09.005, 2004.

Pikridas, M., Tasoglou, A., Florou, K., and Pandis, S. N.: Characterization of the origin of fine particulate matter in a medium size urban area in the Mediterranean, Atmos. Environ., 80, 264-274, doi:10.1016/j.atmosenv.2013.07.070, 2013.

Puxbaum, H., Caseiro, A., Sánchez-Ochoa, A., Kasper-Giebl, A., Claeys, M., Gelencsér, A., Legrand, M., Preunkert, S., and Pio, C.: Levoglucosan levels at background sites in Europe for assessing the impact of biomass combustion on the European aerosol background, J. Geophys. Res., 112, D23S05, doi:10.1029/2006JD008114, 2007.

Robinson, A. L., Subramanian, R., Donahue, N. M., BernardoBricker, A., and Rogge, W. F.: Source apportionment of molecular markers and organic aerosol, 3. Food Cooking Emissions, Environ. Sci. Technol., 40, 7820-7827, doi:10.1021/es060781p, 2006.

Rollins, A. W., Kiendler-Scharr, A., Fry, J. L., Brauers, T., Brown, S. S., Dorn, H.-P., Dubé, W. P., Fuchs, H., Mensah, A., Mentel, T. F., Rohrer, F., Tillmann, R., Wegener, R., Wooldridge, P. J., and Cohen, R. C.: Isoprene oxidation by nitrate radical: alkyl nitrate and secondary organic aerosol yields, Atmos. Chem. Phys., 9, 6685-6703, doi:10.5194/acp-9-6685-2009, 2009.

Saarikoski, S., Carbone, S., Decesari, S., Giulianelli, L., Angelini, F., Canagaratna, M., Ng, N. L., Trimborn, A., Facchini, M. C., Fuzzi, S., Hillamo, R., and Worsnop, D.: Chemical characterization of springtime submicrometer aerosol in Po Valley, Italy, Atmos. Chem. Phys., 12, 8401-8421, doi:10.5194/acp-12-84012012, 2012.

Sage, A. M., Weitkamp, E. A., Robinson, A. L., and Donahue, N. M.: Evolving mass spectra of the oxidized component of organic aerosol: results from aerosol mass spectrometer analyses of aged diesel emissions, Atmos. Chem. Phys., 8, 1139-1152, doi:10.5194/acp-8-1139-2008, 2008.

Schauer, J. J. and Cass, G. R.: Source apportionment of wintertime gas-phase and particle-phase air pollutants using organic compounds as tracers, Environ. Sci. Technol., 34, 1821-1832, doi:10.1021/es981312t, 2000.

Schneider, J., Hock, N., Weimer, S., Borrmann, S., Kirchner, U., Vogt, R., and Scheer, V.: Nucleation particles in diesel exhaust: composition inferred from in situ mass spectrometric analysis, Environ. Sci. Technol., 39, 6153-6161, 2005.

Stein, S. E. and Scott, D. R.: Optimization and testing of mass spectral library search algorithms for compound identification, J. Am. Soc. Mass Spectrom., 5, 859-866, doi:10.1016/10440305(94)87009-8, 1994.
Steinbacher, M., Dommen, J., Ammann, C., Spirig, C., Neftel, A., and Prévôt, A. S. H.: Performance characteristics of a protontransfer-reaction mass spectrometer (PTR-MS) derived from laboratory and field measurements, Int. J. Mass Spectrom., 239, 117-128, doi:10.1016/j.ijms.2004.07.015, 2004.

Stockwell, C. E., Veres, P. R., Williams, J., and Yokelson, R. J.: Characterization of biomass burning emissions from cooking fires, peat, crop residue, and other fuels with high-resolution proton-transfer-reaction time-of-flight mass spectrometry, Atmos. Chem. Phys., 15, 845-865, doi:10.5194/acp-15-845-2015, 2015.

Stohl, A., Forster, C., Frank, A., Seibert, P., and Wotawa, G.: Technical note: The Lagrangian particle dispersion model FLEXPART version 6.2, Atmos. Chem. Phys., 5, 2461-2474, doi:10.5194/acp-5-2461-2005, 2005.

Sueper, D.: ToF-AMS High Resolution Analysis Software - Pika, ToFAMSResources/ToFSoftware, available at: http://cires1.colorado.edu/jimenez-group/wiki/index.php/

High_Resolution_ToF-AMS_Analysis_Guide (last access: 20 February 2017), 2011.

Sun, Y. L., Zhang, Q., Schwab, J. J., Chen, W.-N., Bae, M.-S., Hung, H.-M., Lin, Y.-C., Ng, N. L., Jayne, J., Massoli, P., Williams, L. R., and Demerjian, K. L.: Characterization of near-highway submicron aerosols in New York City with a high-resolution aerosol mass spectrometer, Atmos. Chem. Phys., 12, 2215-2227, doi:10.5194/acp-12-2215-2012, 2012.

Sun, Y.-L., Zhang, Q., Schwab, J. J., Demerjian, K. L., Chen, W.N., Bae, M.-S., Hung, H.-M., Hogrefe, O., Frank, B., Rattigan, O. V., and Lin, Y.-C.: Characterization of the sources and processes of organic and inorganic aerosols in New York city with a high-resolution time-of-flight aerosol mass apectrometer, Atmos. Chem. Phys., 11, 1581-1602, doi:10.5194/acp-11-15812011, 2011.

Theodosi, C., Grivas, G., Zarmpas, P., Chaloulakou, A., and Mihalopoulos, N.: Mass and chemical composition of sizesegregated aerosols $\left(\mathrm{PM}_{1}, \mathrm{PM}_{2.5}, \mathrm{PM}_{10}\right)$ over Athens, Greece: local versus regional sources, Atmos. Chem. Phys., 11, 1189511911, doi:10.5194/acp-11-11895-2011, 2011.

Trainer, M. G., Jimenez, J. L., Yung, Y. L., Toon, O. B., and Tolbert, M. A: Nitrogen incorporation in $\mathrm{CH}_{4}-\mathrm{N}_{2}$ photochemical aerosol produced by far ultraviolet irradiation, Astrobiology, 12, 315326, doi:10.1089/ast.2011.0754, 2012.

Turpin, B. J. and Huntzicker, J. J.: Identification of secondary organic aerosol episodes and quantitation of primary and secondary organic aerosol concentrations during SCAQS, Atmos. Environ., 29, 3527-3544, doi:10.1016/1352-2310(94)00276-Q, 1995.

Ulbrich, I. M., Canagaratna, M. R., Zhang, Q., Worsnop, D. R., and Jimenez, J. L.: Interpretation of organic components from Positive Matrix Factorization of aerosol mass spectrometric data, Atmos. Chem. Phys., 9, 2891-2918, doi:10.5194/acp-9-2891-2009, 2009.

Vlasenko, A., Slowik, J. G., Bottenheim, J. W., Brickell, P. C., Chang, R. Y.-W., Macdonald, A. M., Shantz, N. C., Sjostedt, S. J., Wiebe, H. A., Leaitch, W. R., and Abbatt, J. P. D.: Measurements of VOCs by proton transfer reaction mass spectrometry at a rural Ontario site: Sources and correlation to aerosol composition, J. Geophys. Res., 114, D21305, doi:10.1029/2009JD012025, 2009. 
Watson, J. G.: Visibility: Science and Regulation, J. Air Waste Manage. Assoc., 52, 628-713, doi:10.1080/10473289.2002.10470813, 2002.

Wotawa, G. and Trainer, M.: The influence of Canadian forest fires on pollutant concentrations in the United States, Science, 288, 324-328, doi:10.1126/science.288.5464.324, 2000.

Zhang, Q., Jimenez, J. L., Canagaratna, M. R., Allan, J. D., Coe, H., Ulbrich, I., Alfarra, M. R., Takami, A., Middlebrook, A. M., Sun, Y. L., Dzepina, K., Dunlea, E., Docherty, K., DeCarlo, P. F., Salcedo, D., Onasch, T., Jayne, J. T., Miyoshi, T., Shimono, A., Hatakeyama, S., Takegawa, N., Kondo, Y., Schneider, J., Drewnick, F., Borrmann, S., Weimer, S., Demerjian, K., Williams, P., Bower, K., Bahreini, R., Cottrell, L., Griffin, R. J., Rautiainen, J., Sun, J. Y., Zhang, Y. M., and Worsnop, D. R.: Ubiquity and dominance of oxygenated species in organic aerosols in anthropogenically-influenced Northern Hemisphere midlatitudes, Geophys. Res. Lett., 34, L13801, doi:10.1029/2007GL029979, 2007. 